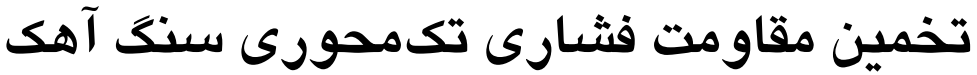

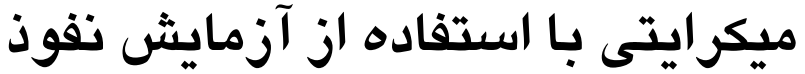

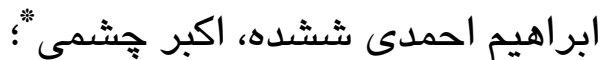 \\ دانشكاه تهران، يرديس علوم، دانشكده زمينشناسى احسى \\ يذيرش

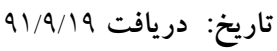 \\ حكکده
}

تعيين مقاومت فشارى تكمحورى (UCS) سنخ در بيشتر يروزههاى مهندسى ضرورى

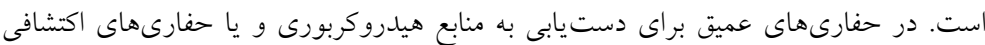

براى تونلهاى عميق تهيئ نمونه مناسب براى اندازهيرى مستقيم UCS مشكل، هزينهبر و كاهى غيرممكن است. بنا بر اين استفاده از روشهاى غيرمستقيم (نظير استفاده از خردههاى حفارى) براى تخمين UCS متداول شده است. استفاده از نفوذ كننداى سخت كه به داخل

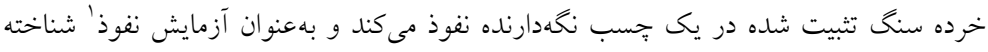
مىشود، يكى از اين روشها است. در اين مقاله تعداد ^ نمونه سنگ آهك ميكرايتى تهيه و يس از تعيين UCS آنها در آزمايشخاه، نمونهها خرد و آزمايش نفوذ با نفوذ كندههايى به

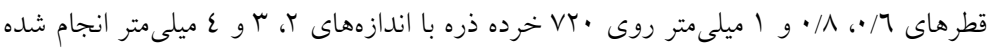
و نيروى انتقال بحرانى (CTF) كه معرف مقاومت نهايى خرده ذره در مقابل ورود نفوذكننده به روس داخل آن است، تعيين شده است. روابط تجربى بين UCS و CTF براى نمونهها و نفوذكنندهاى با قطرهاى مختلف با R² 0.78 ييشنهاد شده است. با استفاده از رخرسيون جند متغيره، رابطهاى كلى بين UCS، CTF، اندازه ذرات (D) و قطر نفوذكننده (I) با R = 0.85 ارائه شده است. صحت روابط تجربى بيشنهادى با انجام هبا آزمايش نفوذ روى ب نمونه سنى آهى ميكرايتى و مقايسه UCS اندازهيرى شده در آزمايشگاه با UCS تخمين زده شده ارزيابى شده

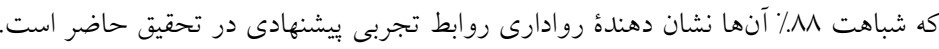

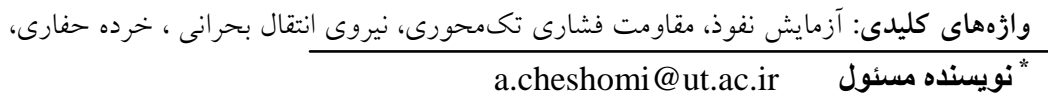

\section{Indentation test}




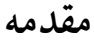

مقاومت فشارى تكمحورى سنگ (UCS) از كاربردى ترين پارامترهاى مكانيكى سنگ

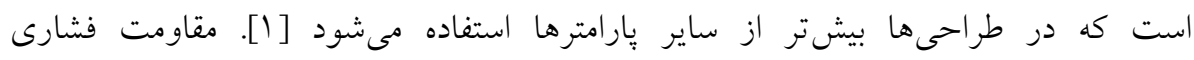

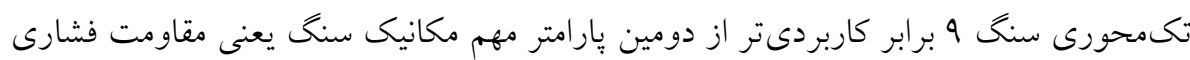

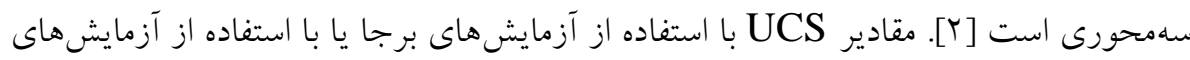

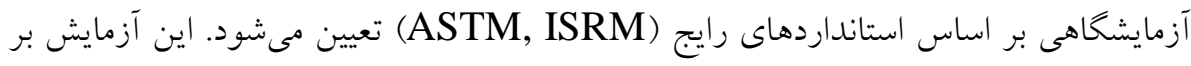
خلاف سادكى فهم و درك منطق آن، به نسبت كرانقيمت و مستلزم صرف وقت زيادى است.

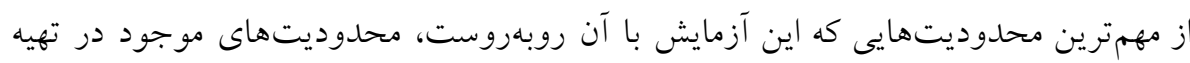

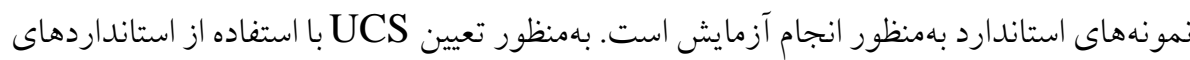

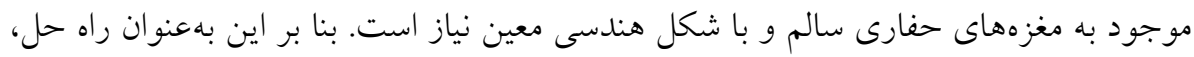
در مواردى كه تهية نمونههاى استاندارد مقدور نيست، محققان به تعيين UCS سنخ با استفاده از روش هاى غيرمستقيم توجه كردهاند.

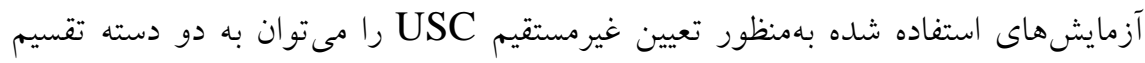

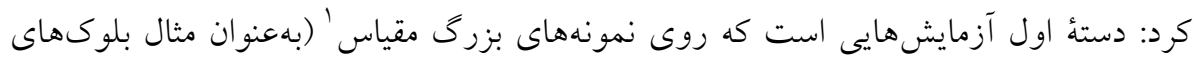

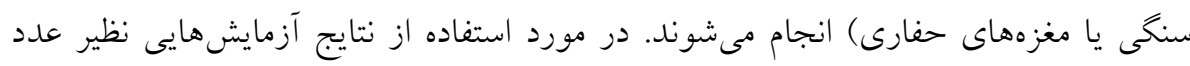

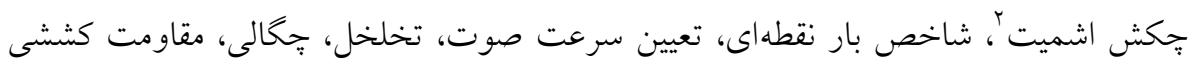

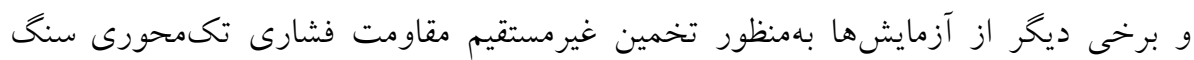

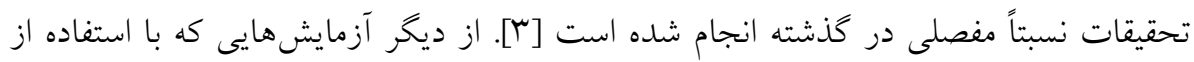
آنها مقاومت فشارى تكمححورى بهصورت غيرمستقيم تعيين مى شود مى توان به آزمايش يانج

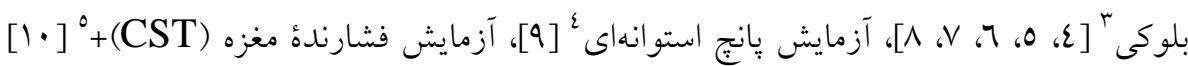

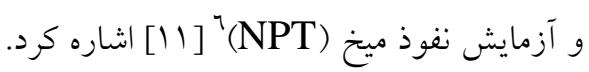

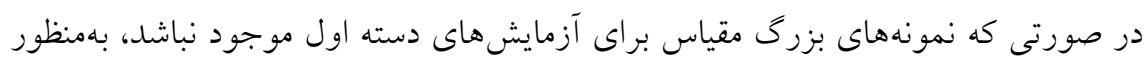

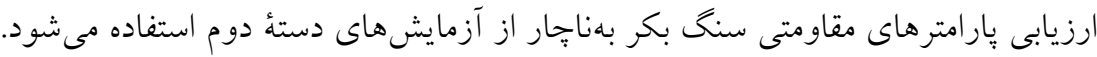

1. Big-Scale Rock Samples 4. Cylindrical lunch test
2. Schmitt Iammer 5. Core Strangle Test
3. Block lunch test

6. Nail Penetration Test 
در اين دسته از آزمايشها با استفاده از نمونههاى كوجى مقياس (بهعنوان مثال خردههاى

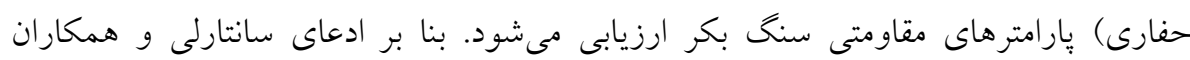

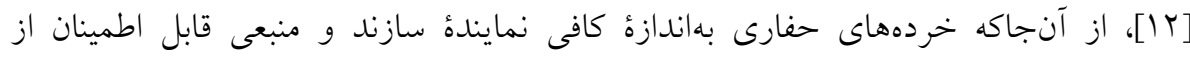

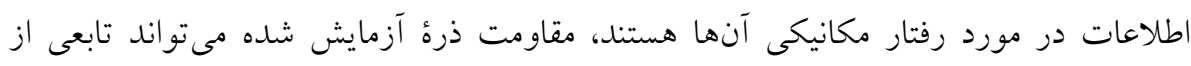

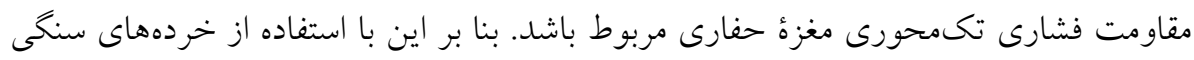

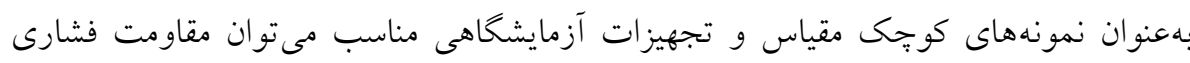

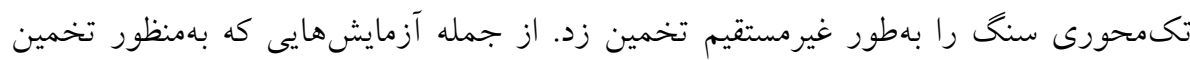

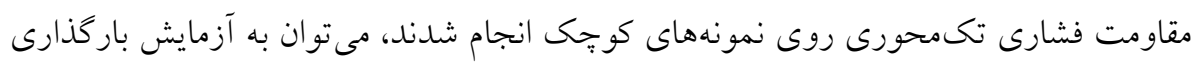

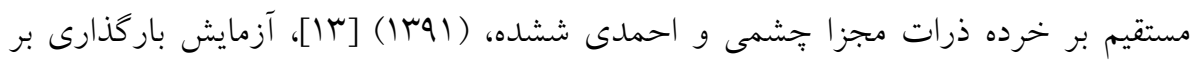

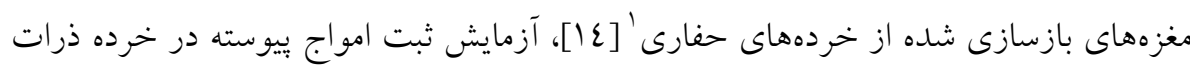

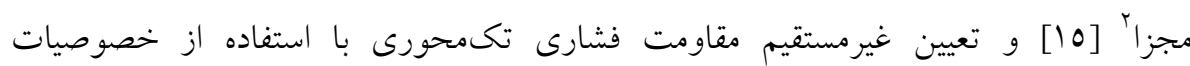
سنخشناسى [I [IV]، [IV] اشاره داشت.

آزمايش نفوذ نيز از روشهايى است كه بهمنظور ارزيابى يارامترهاى مقاومتى خردههاى حفارى استفاده شده است [1/]. در اين آزمايش نفوذكندهاى سخت با ميزان كرنش ثابت در خرده ذرات سنكى نفوذ داده شده، ضمن نفوذ پارامترهاى مقاومتى سنگ ارزيابى مى شوده.

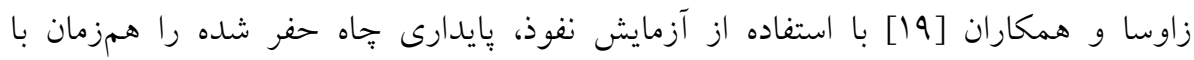
عمليات حفارى بررسى كردند. رينگاستاد و همكاران [11] با استفاده از همبستخى خطى بين

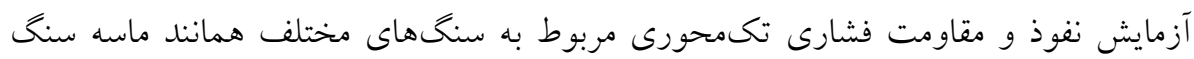

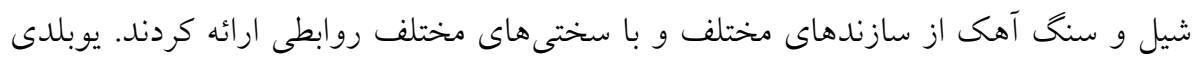
و همكاران [•r] يزوهشهايى براى انتخاب خردههاى حفارى با آزمايش نفوذ انجام دادند.

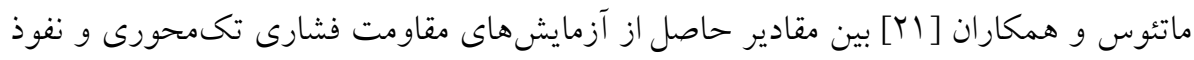

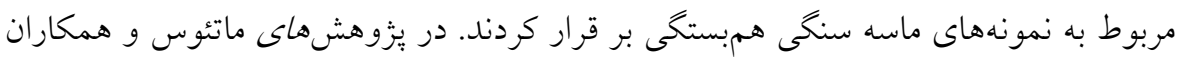


بهمنظور تعيين غيرمستقيم مقاومت فشارى تكمحورى سنگ يارامترهاى مقاومتى بهدست آمده

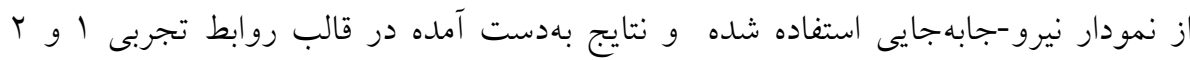

$$
\begin{array}{lll}
U C S=17.38(I M) & , & R^{2}=0.81 \\
U C S=91.97(C T F) & , & R^{2}=0.70
\end{array}
$$$$
\text { ا رائه شده است. }
$$

نيروى انتقال بحرانى' (نيروى ثبت شده تا زمان ورود نفوذكننده به نمونه بر حسب CTF

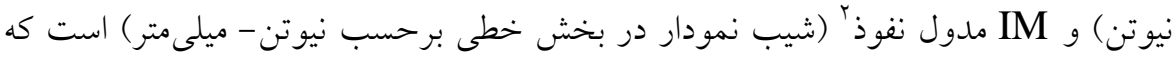
مطابق شكل ا از نمودار نيرو جابهجايى مربوط به آزمايش نفوذ بهدست مى آيد.

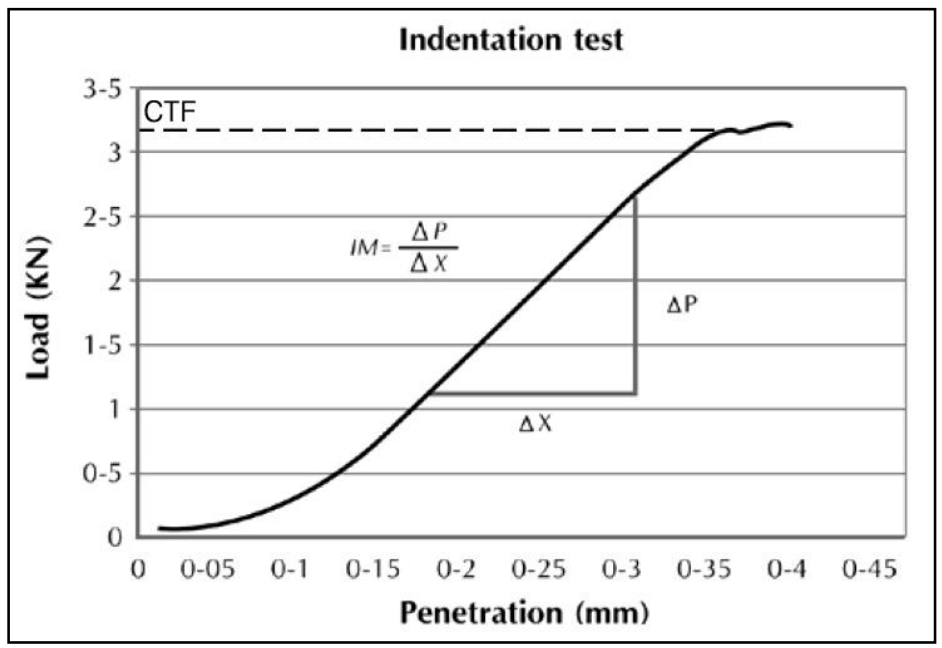

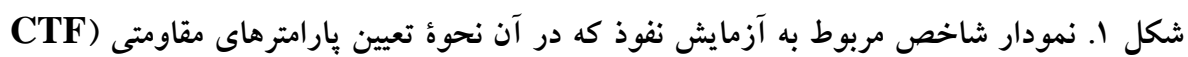

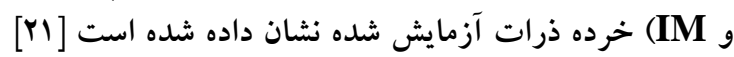

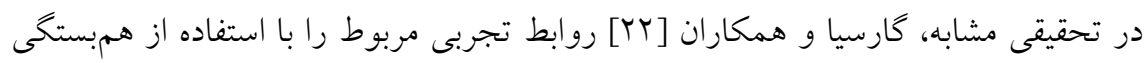

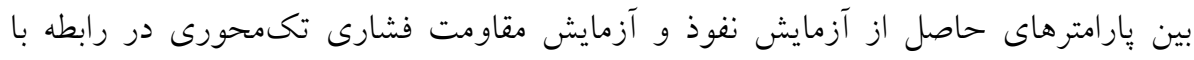

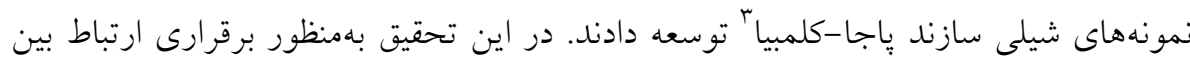

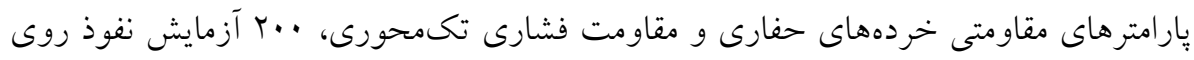

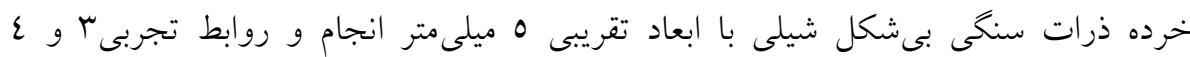
بيشنهاد شد.

1. Critical Transitional Force 2. Indentation Modulus 3. Paja Formation 


$$
\begin{aligned}
& U C S=0.0005(I M)^{2}+3.2847(I M) \quad, \quad R^{2}=0.6513 \quad \text { (r) } \\
& U C S=-0.0083(C T F)^{2}+33.082(C T F) \quad, \quad R^{2}=0.8111
\end{aligned}
$$

\section{روش انجام كار}

\section{تهيه و آمادهسازى نمونههاى سنخى}

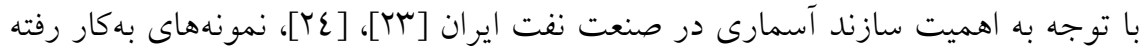
در اين تحقيق عمدتاً از سنگهاى كربناته سازند آسمارى انتخاب شده است. بدينمنظور 9 بلوى سنگى از رخنمونهاى سازند آسمارى و Ү بلوك سنكى از رخنمون سازندهاى تله زنخ و سروى (با ابعاد تقريبى •ع×•ع×•r سانتىمتر) تهيه و به آزمايشگاه انتقال داده شده است. در جدول ا مشخصات جينهنگارى، يارامترهاى فيزيكى و مقاومتى مربوط به نمونهاى سنخى

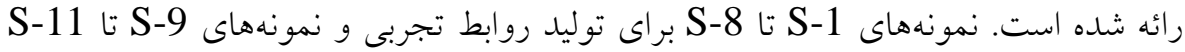
بهمنظور ارزيابى صحت روابط تجربى استفاده شده است. براى آزمايش مقاومت فشارى تكمحورى از هر بلوى سنكى 0 مغزه سنكى كاملاً بكر

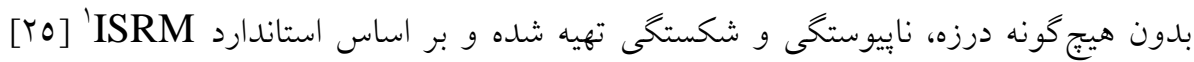

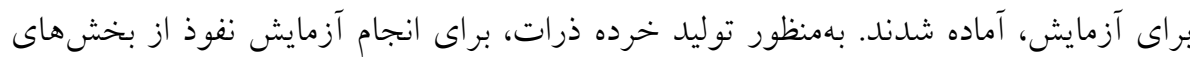
باقىمانده مربوط به مغزههاى سنكى استفاده شده است. از آنجاكه در تحقيق حاضر هدف از آزمايش نفوذ علاوه بر بررسى رابطة تجربى بين UCS و CTF، بررسى اثر اندازه خرده ذرات و قطر نفوذكننده است از اين رو، نمونهاى مربوط به آزمايش نفوذ، همشكل و بلصورت مكعبهاى همبعد در سه اندازه r ، r و ع ميلىمترى آمادهسازى شدهاند. بدينمنظور ابتدا

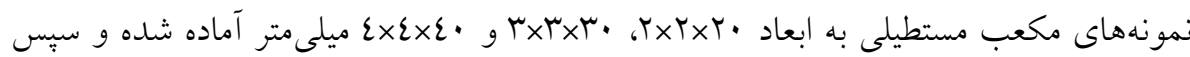
با استفاده از سنگجين و سوهان بهصورت مكعبهاى همبعد جيده و بخشهاى ناهموار آن اصلاح و خرده ذرات مكعبى شكل در ابعاد r، r و ع ميلىمترى توليد شده است. مراحل 1. International Society of Rock Mechanics آمادهسازى نمونهاى خرده سنخى مكعبى در شكل ب نشان داده شده است. 
جدول 1. مشخصات جينهنگارى، فيزيكى و مقاومتى نمونهاى سنكى برداشت شده

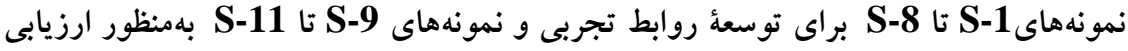
صحت نتايج تجربى ارائه شده به وكار رفتهاند.

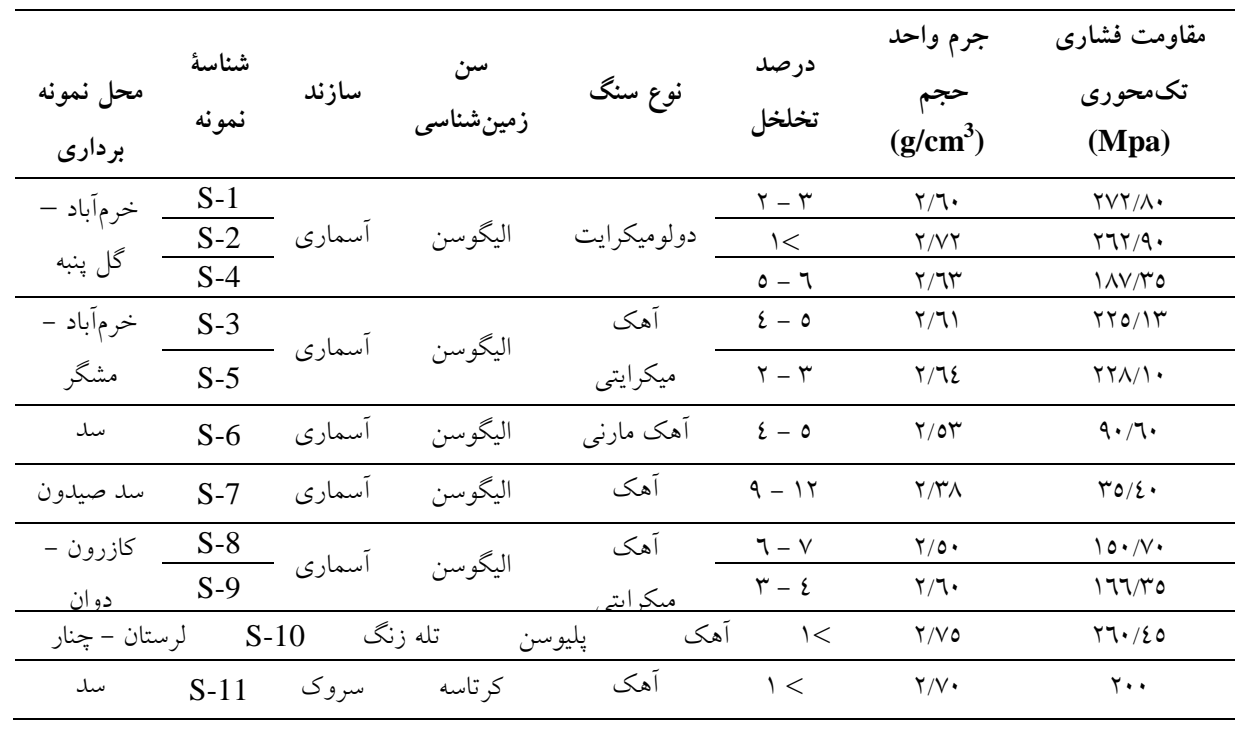

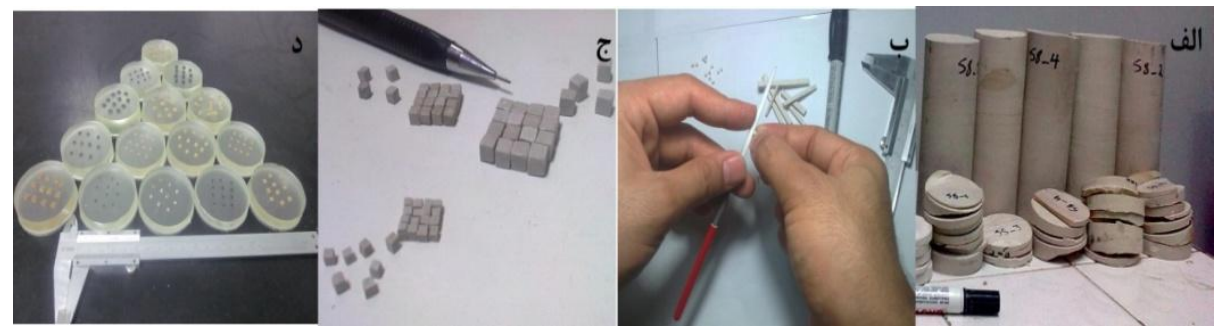

شكل r. مراحل آمادهسازى خرده ذرات سنخى مكعبى شكل مربوط به آزمايش نفوذ: الف)

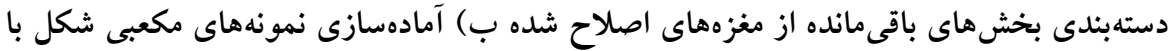

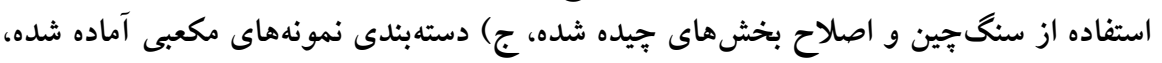

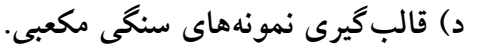

بهمنظور ثابت كردن نمونههاى مكعبى آماده شده در حين آزمايش نقوذ، نمونههاى مربوط در جسب صنعتى (با نام تجارى ML-506) قالب گيرى شدند. مشخصات جسب مذكور در جدول r ارائه شده است. 
جدول r. بارامترهاى فيزيكى و مكانيكى جسب قالبگيرى (ML-506)

\begin{tabular}{|c|c|c|c|c|c|c|c|c|c|}
\hline فقاومت & فشارى 1 فارى & مقاومت & مدول & كشتى استحام & مدول كشى & 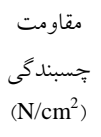 & ضقاومت & مخصوص وزن & ويسكوزيته \\
\hline$q v \varepsilon$. & arvi. & 97. & razos. & v71. & rVAq.. & ofA. & $\Lambda V / O$. & $1 / 11$ & $1 \varepsilon 0$. \\
\hline
\end{tabular}

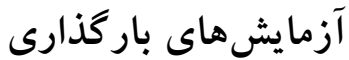

آزمايش فشارى تكمحورى

روى مغزههاى سنگى آماده شده (0 مغزه سنگى كاملاً بكر از هر بلوك سنگى) مطابق استاندارد ISRM و در رطوبت طبيعى، آزمايش باركذارى فشارى تكمحورى انجام شده

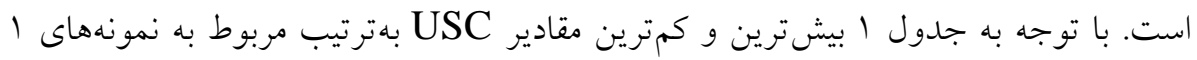

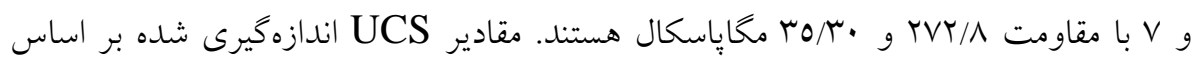

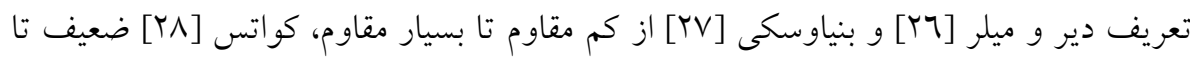
خيلى قوى، IAEG، ISRM و انجمن زمينشناسى بريتانيا [Y9] نسبتاً قوى تا بسيار قوى و و

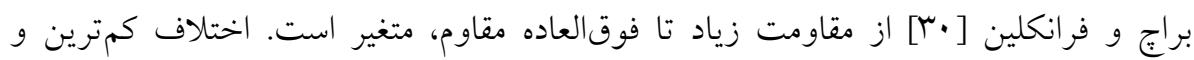
بيشترين مقادير USC در تحقيق حاضر معادل MPa است كه با توجه به توصية

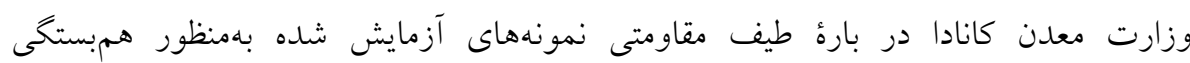

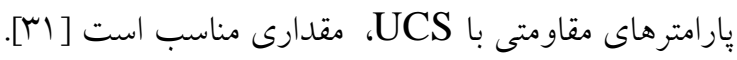

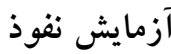

در شكل r الف نحوه اعمال بار و سيستم ثبت تغييرات در آزمايش نفوذ نشان داده شده

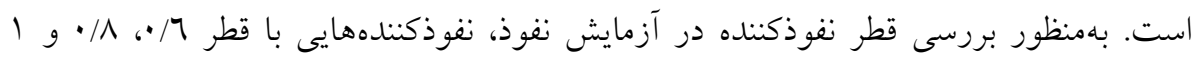

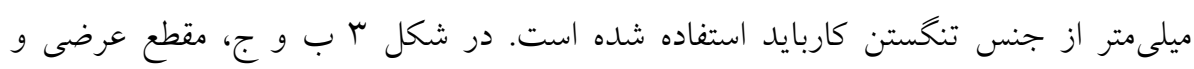

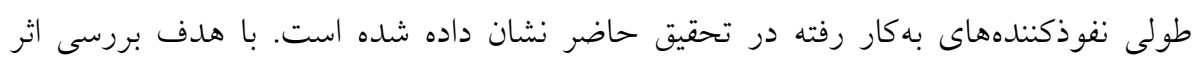




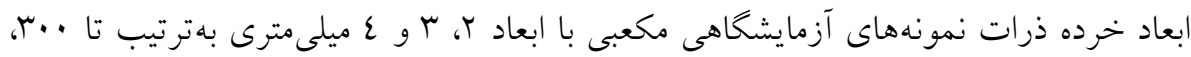

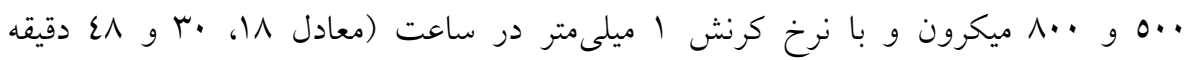

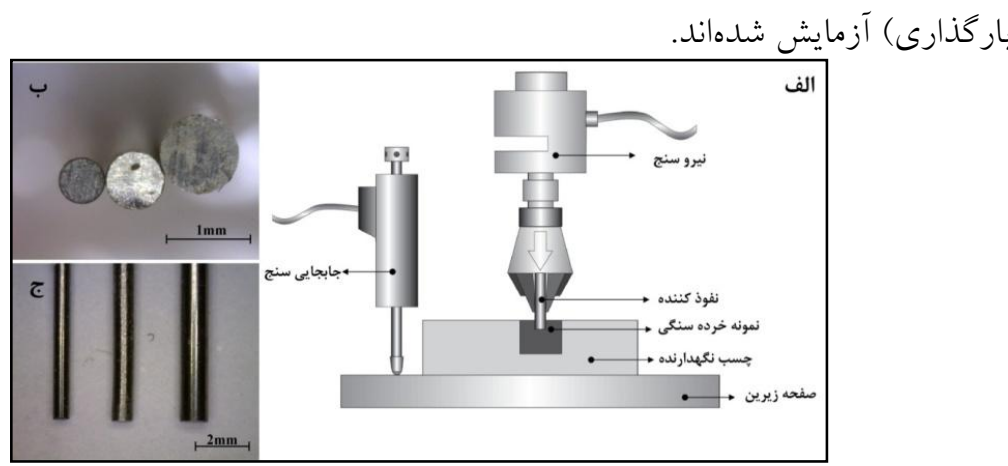

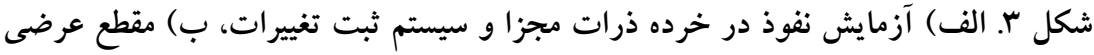

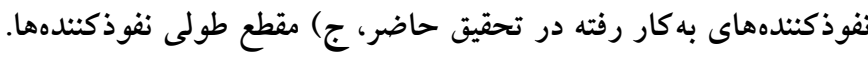

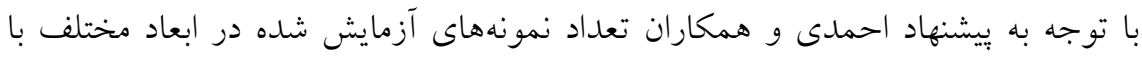

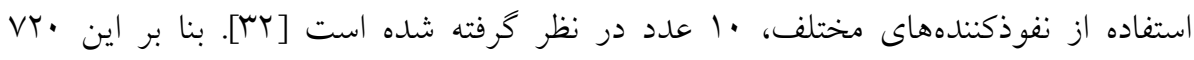

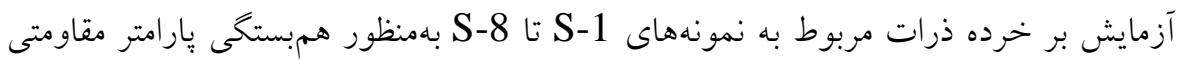

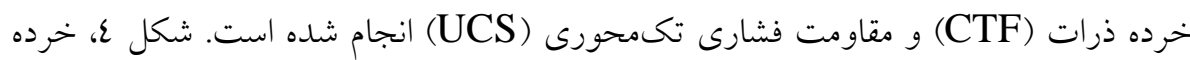
ذرات آزمايش شده در ابعاد مختلف را يس از آزمايش نفوذ با استفاده از نفوذكندههاى مختلف

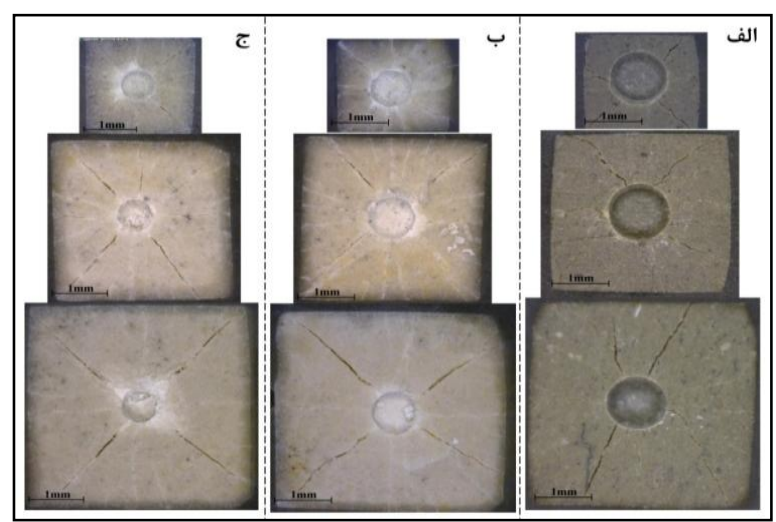

نشان مىدهد.

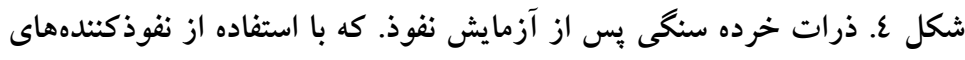

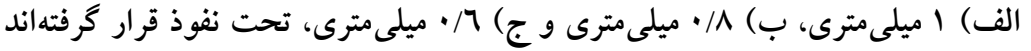




$$
\text { نتايج آزمايش هاى آزمايشخاهى }
$$

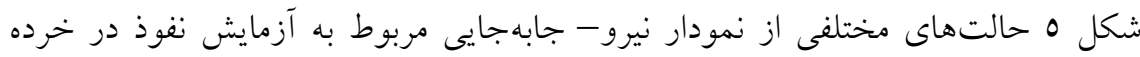

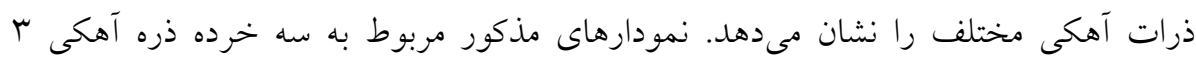

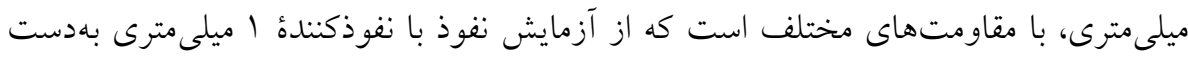
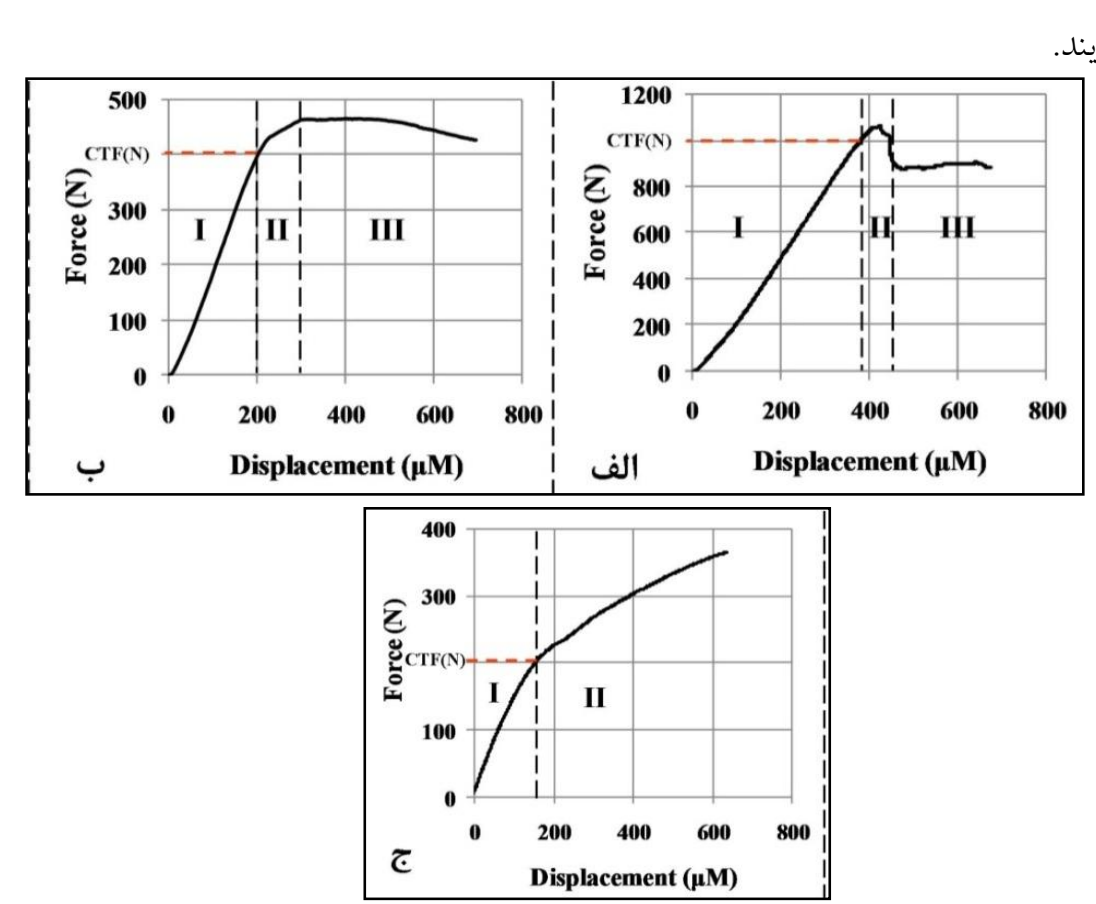

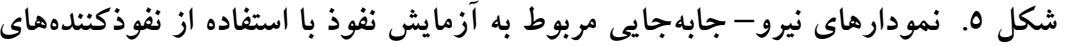

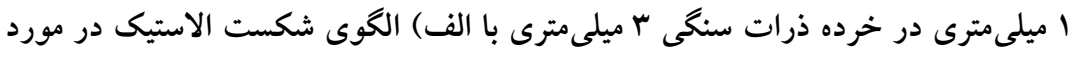

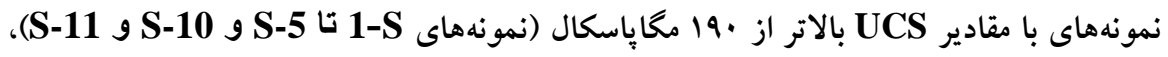

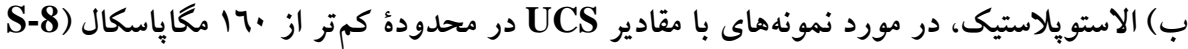

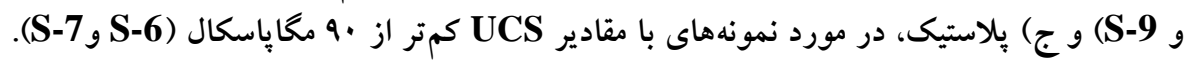
با توجه به شكل 0، سه ناحئ متمايز در نمودارها قابل تشخيص است. ناحيئ I كه بهصورت

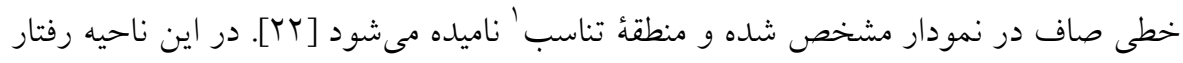
1. Proportionality zone 
نمونه تحت اعمال بار از نوع الاستيك است. ناحية II لبهعنوان ناحيةُ كارار معرفى مىشود كه

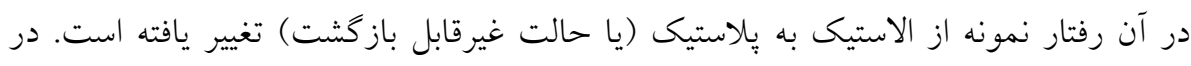

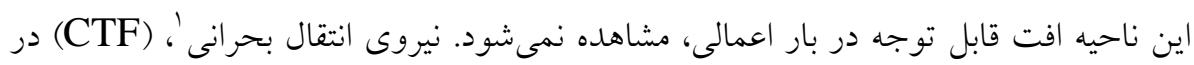

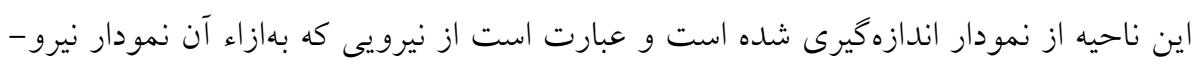
جابهجايى از حالت خطى خارج شده است. اين يارامتر بر حسب نيوتن اندازهيرى مىشود و

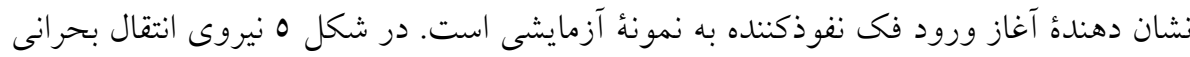
حداكثر نيروى ثبت شده در انتهايىترين بخش ناحية I و ابتدايىترين بخش ناحئ II II است.

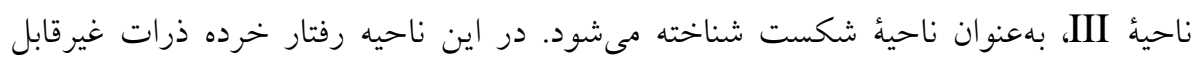

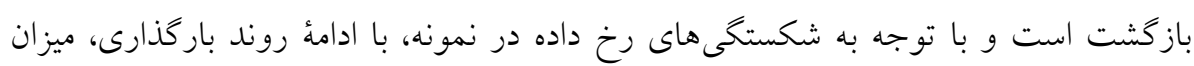

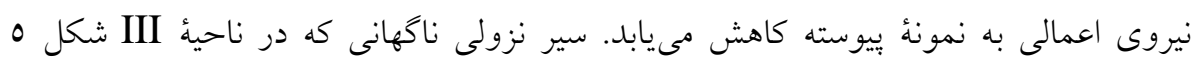

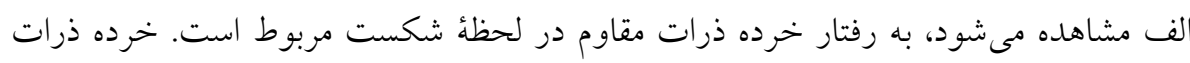

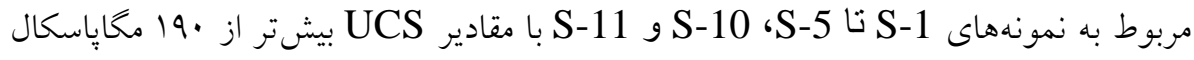
داراى جنين الكوى رفتارى (الكوى رفتارى الاستيك) در لحظة كسيختكى هستند.

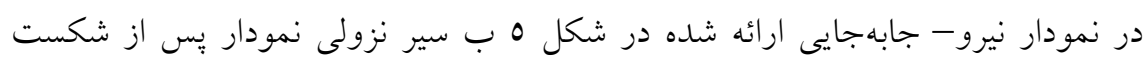

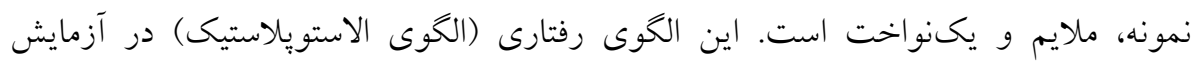

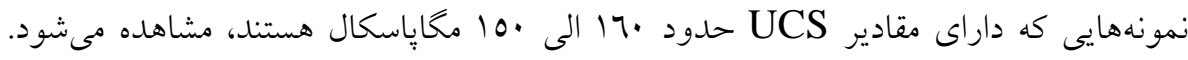

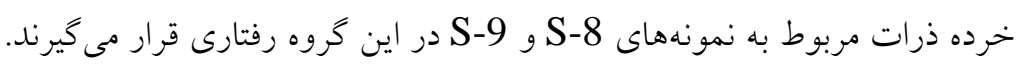

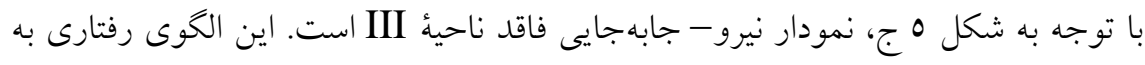

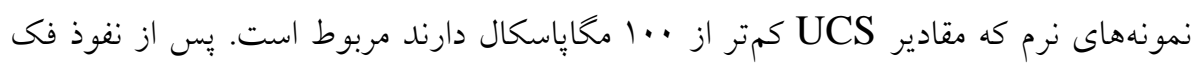

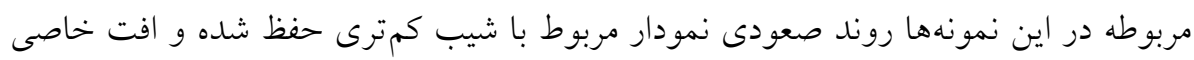

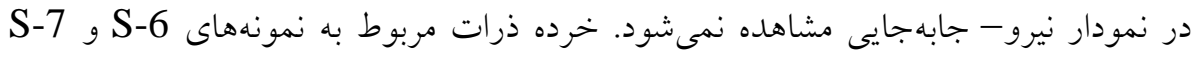
داراى اين الخوى رفتارى (الخوى رفتارى بِاستيك) هستند.

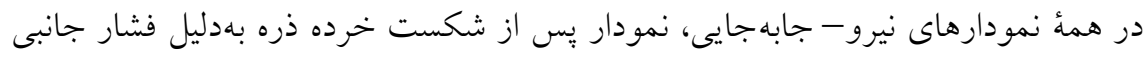

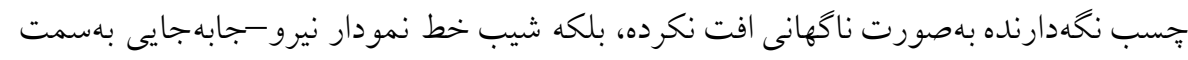


صفر ميل مى كند. در اين حالت نمونه بهطور كلى كسيخته شده و ميزان نيروى باقىمانده، به

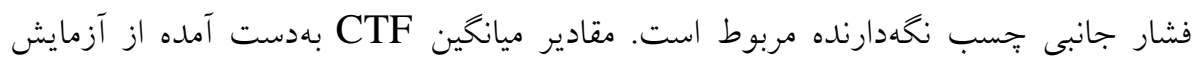

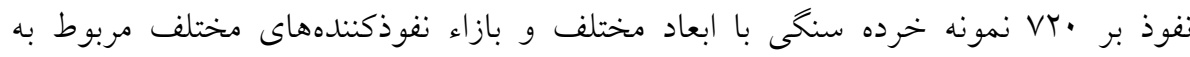

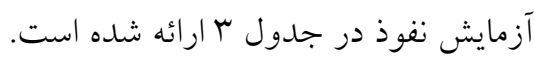

بهمنظور ارزيابى دقت دادههاى بهدست آمده و بررسى كفايت تعداد آزمايشهاى آندائ انجام

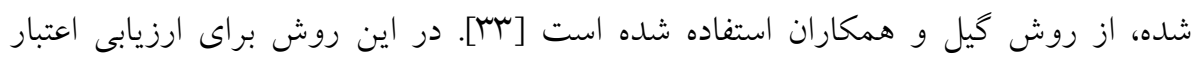

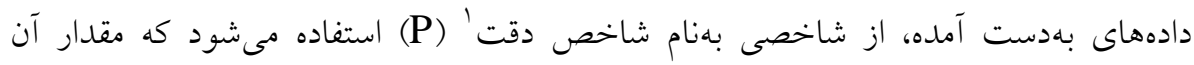

$$
\text { همواره از ا بيشتر است و از رابطة (0) محاسبه مىشود: }
$$

X 

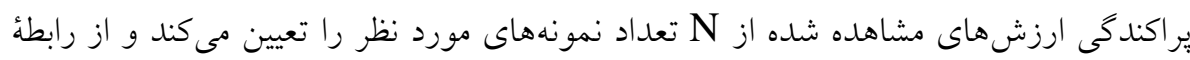

$$
s=\sqrt{\frac{\sum_{i=1}^{N}\left(X_{i}-\bar{X}\right)^{2}}{N-1}}
$$

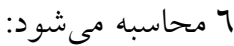

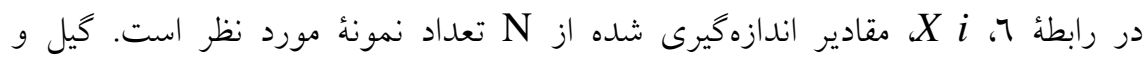

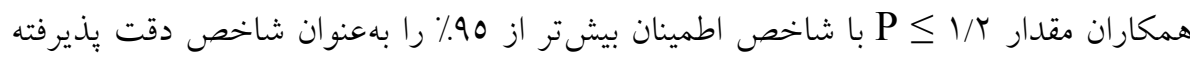

$$
\text { شده در فعاليتهاى يزوهشى دقيق معرفى كردهاند. }
$$

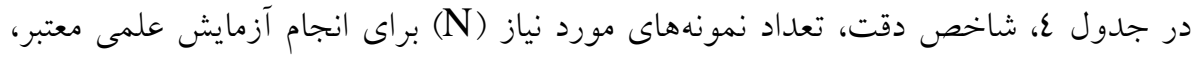

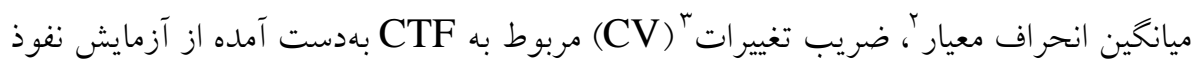

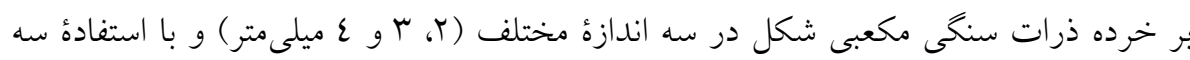

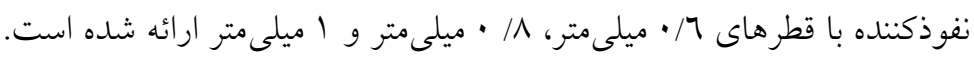




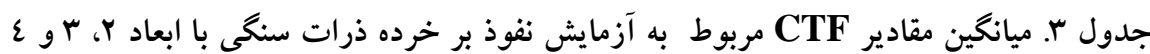

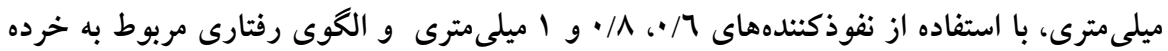

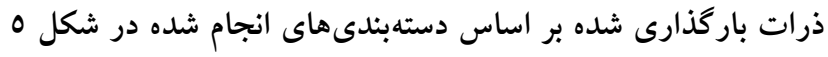

\begin{tabular}{|c|c|c|c|c|c|c|}
\hline \multirow{3}{*}{ شناسه نمونه } & \multirow{3}{*}{$\begin{array}{c}\text { UCS } \\
\text { (MPa) }\end{array}$} & \multirow{3}{*}{ ذاندازه خرده } & \multicolumn{3}{|c|}{ قطر نفوذ كنده (mm) } & \multirow{3}{*}{ الخوى رفتارى } \\
\hline & & & $\cdot / 7$ & $\cdot / A$ & 1 & \\
\hline & & & \multicolumn{3}{|c|}{ CTF (N) ميانخين } & \\
\hline \multirow{3}{*}{ S-1 } & \multirow{3}{*}{$T V Y / \Lambda$. } & r & $r u / \cdot r$ & $\sum Y q / 9 \Lambda$ & $\sum \wedge q / 9 \vee$ & \multirow{3}{*}{ الاستيك } \\
\hline & & r & $00 \cdot 107$ & $V 10 / 90$ & Q६V/VV & \\
\hline & & $\varepsilon$ & $T V A / \Gamma q$ & $\Lambda \wedge \varepsilon / 1$. & $11 \varepsilon 7 / 7$. & \\
\hline \multirow{3}{*}{ S-2 } & \multirow{3}{*}{$r 7 r / 9}$. & r & rVN/Tr & $7 \Sigma 7 / V q$ & $\varepsilon r q / T V$ & \multirow{3}{*}{ الاستيك } \\
\hline & & r & OrT/IT & $79 Y / .7$ & $799 / \mu 1$ & \\
\hline & & $\varepsilon$ & $0 \vee 9 / 10$ & $V \varepsilon \varepsilon / 0 \Lambda$ & $1 . r T / r$. & \\
\hline \multirow{3}{*}{$S-3$} & \multirow{3}{*}{$1 \Lambda V / r O$} & r & $r \cdot \varepsilon / 0$. & $\varepsilon \mid V / \varepsilon$. & $\varepsilon 1 \varepsilon / v q$ & \multirow{3}{*}{ الاستيك } \\
\hline & & $r$ & $\varepsilon \mid \Lambda / \cdot 1$ & $0 \wedge \cdot / 71$ & $79 \cdot / N r$ & \\
\hline & & $\varepsilon$ & $0 . V / 0 \varepsilon$ & $O \vee q / \Sigma \wedge$ & M M & \\
\hline \multirow{3}{*}{ S-4 } & \multirow{3}{*}{ rro/Ir } & r & MT/AV & $\varepsilon \cdot 0 / 19$ & $\varepsilon Q Y / T q$ & \multirow{3}{*}{ الاستيك } \\
\hline & & $r$ & $\varepsilon+1 / 01$ & OVN/TY & $\Lambda \cdot\{/ \Lambda\rceil$ & \\
\hline & & $\varepsilon$ & $0 . V / 91$ & $V T 9 / 0$. & $1.79 / \varepsilon$. & \\
\hline \multirow{3}{*}{ S-5 } & \multirow{3}{*}{ TYN/I. } & r & 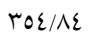 & $\mathrm{rqV} / \varepsilon \mathrm{V}$ & $\{\Lambda 1 / \varepsilon \Lambda$ & \multirow{3}{*}{ الاستيك } \\
\hline & & $r$ & $\{0 N / 2\}$ & $709 / V 9$ & $177 / 11$ & \\
\hline & & $\varepsilon$ & $7 r Y / 1$. & $\Lambda \cdot \sum / V 7$ & $\mid r T r / T$. & \\
\hline \multirow{3}{*}{ S-6 } & \multirow{3}{*}{$9 \cdot / 7}$. & r & 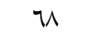 & $|r| / \cdot r$ & $191 / 7 \varepsilon$ & \multirow{3}{*}{ بِلاستيك } \\
\hline & & $r$ & $\Lambda \mathrm{V}$ & $|\varepsilon| / \varepsilon q$ & $r|r / \mu|$ & \\
\hline & & $\varepsilon$ & 11. & $1 W / 11$ & rot/M & \\
\hline \multirow{3}{*}{ S-7 } & \multirow{3}{*}{ ro/z. } & r & $1 .$. & $100 / 19$ & $r \mu \varepsilon / v$. & \multirow{3}{*}{ ي بِلاستيك } \\
\hline & & r & 11. & $\mid r o / \cdot r$ & 17. & \\
\hline & & $\varepsilon$ & $9 r / 0$. & $17 r / 91$ & 100 & \\
\hline \multirow{3}{*}{ S-8 } & \multirow{3}{*}{$10 \cdot / V$} & r & $195 / r$. & rYI & $r q \varepsilon / r$. & \multirow{3}{*}{ الاستو يلاستيك } \\
\hline & & r & TMT & rro & $\varepsilon \wedge Y / T$. & \\
\hline & & $\varepsilon$ & roo & ror/o. & 01. & \\
\hline
\end{tabular}

با توجه به نتايج ارائه شده در جدول ع با كاهش قطر نفوذكننده و افزايش ابعاد خرده ذره آزمايش شده ضريب تغييرات، تعداد نمونههاى لازم براى انجام آزمايشى علمى و شاخص دقت كاهش يافته است. به اين معنا كه با افزايش قطر خرده ذرات و كاهش قطر نفوذكننده، نتايج مربوط از تكراريذيرى بيشترى برخوردارند. با توجه به شاخص N در جدول، تعداد 
نمونهاى آزمايش شده (•ا عدد در هر اندازه و با هر قطر نفوذكنده) بهمنظور ارزيابى مقاومت خرده ذرات سنكى كافى بوده است.

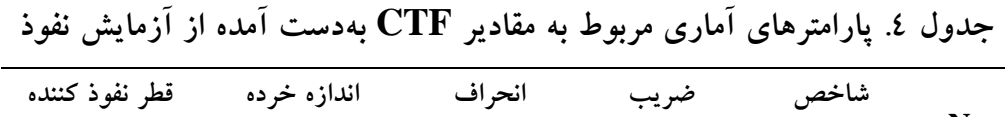

\begin{tabular}{|c|c|c|c|c|c|}
\hline$(\mathbf{m m})$ & ذرات (mm) & معيار & تغييرات (\%) & دقت & $\mathbf{N}$ \\
\hline \multirow{3}{*}{$\cdot / 7}$. & r & $T V / T q$ & V/AO & $1 / 1 \pi$ & 0 \\
\hline & $r$ & $20 / 01$ & 9/or & $1 / 17$ & V \\
\hline & $\varepsilon$ & ro/77 & T/IV & $1 / 1$. & $\varepsilon$ \\
\hline \multirow{3}{*}{$\cdot / \Lambda}$. & r & $r Y / 71$ & $N / \Gamma \varepsilon$ & $1 / 1 \varepsilon$ & 7 \\
\hline & $r$ & $r q / q r$ & $V / N I$ & $1 / T r$ & 0 \\
\hline & $\varepsilon$ & $\varepsilon \varepsilon / \mu_{\Lambda}$ & $\mathrm{V} / \mathrm{A}$ & $1 / 11$ & $\varepsilon$ \\
\hline \multirow{3}{*}{1} & $r$ & $r ד / r V$ & $\Lambda / V \varepsilon$ & $1 / 1 \varepsilon$ & 7 \\
\hline & $r$ & $O N / \varepsilon q$ & זר/א & $1 / 1 \varepsilon$ & 7 \\
\hline & $\varepsilon$ & $V_{T / O 1}$ & $\Lambda / \Lambda$ & $1 / 1 \pi$ & 0 \\
\hline
\end{tabular}

\section{همبستخى بين CTF و}

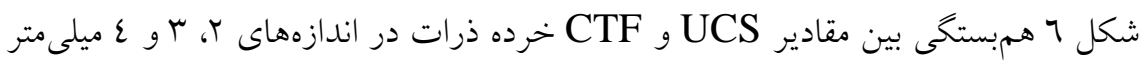
كه با نفوذكندة 7/· ميلىمترى آزمايش شدهاند را نشان مىدهد. با افزايش اندازه خرده ذرات، شيب خطوط برازش داده شده كاهش يافته است. با اين حال مقادير بالاى ضرايب تعيين' (C.D.)

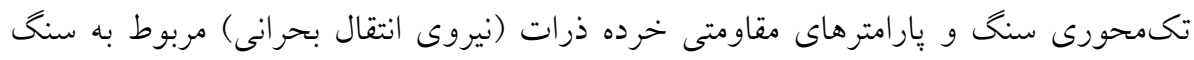
مورد نظر است. با توجه به شكل 7، بيشترين همبستخى مربوط به ذرات ب و ع ميلىمترى و

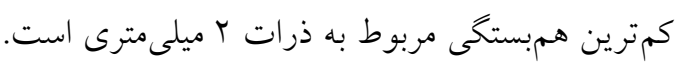
شكل V، همبستخى CTF-UCS خرده ذرات r ميلى مترى كه با نفوذكننده داراى قطرهاى 1/ •، 1/ • و ا ميلى مترى آزمايش شدهاند را نشان مىدهد. جنانكه مشاهد مىشوده، با افزايش

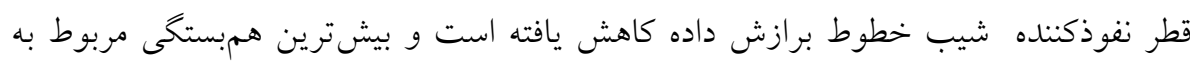
نفوذكنندهاى 1/ • و // • ميلىمترى و كمترين همبستخى مربوط به نفوذكنندة اميلى مترى است. 1. Confection of Determination 


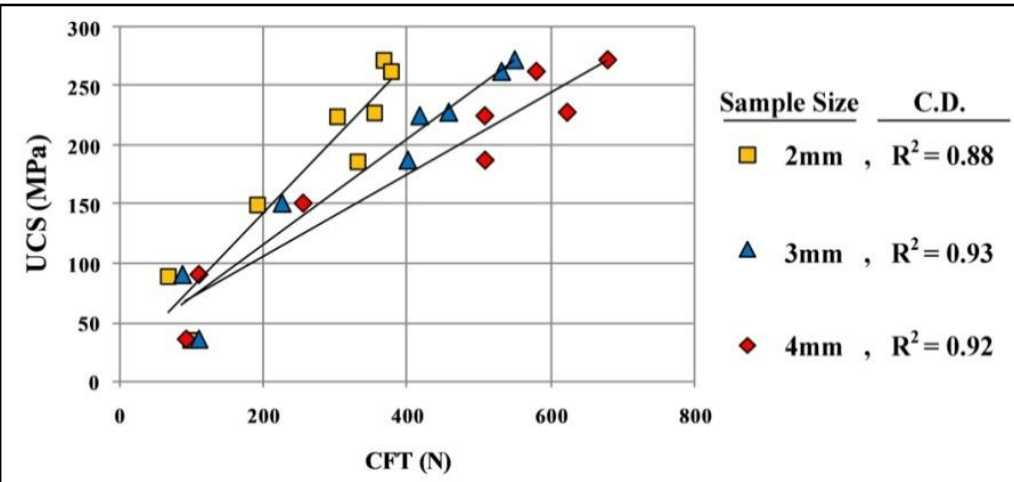

شكل 7. همبستخى CTF-UCS مربوط به خردههاى سنگى r، r و ع ميلى مترى كه با نفوذكننده 7/ • ميلى مترى آزمايش شدهاند

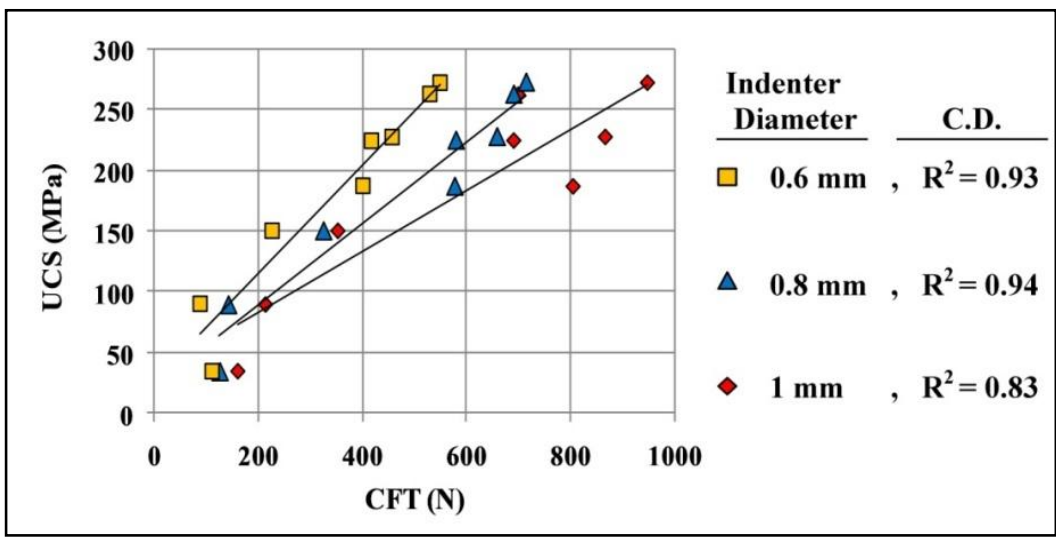

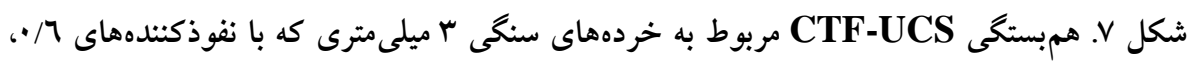

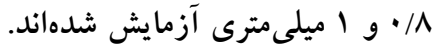

با اين حال مقادير زياد ضرايب تعيين مربوط به همبستخى هاى برقرار شده، نشاندهنده ارتباط خوب بين مقاومت فشارى تكىحورى سنگ و يارامترهاى مقاومتى خرده ذرات (نيروى انتقال بحرانى) بازاى نفوذكننده با قطرهاى مختلف است. شكلهاى 7 و V بهروشنى نشان مىدهند كه اندازه خرده ذرات و قطر نفوذكننده در همبستخى هاى برقرار شده تاثير گذار است. با توجه به اين كه در تحقيق حاضر خرده ذرات در سه اندازهُ مختلف با سه نفوذكنده با قطرهاى مختلف آزمايش شدهاند از اين رو، 9 رابطهٔ تجربى به شرح جدول ه براى تخمين UCS از روى CTF يبشنهاد شده است. ضرايب تعيين 
براى هر كدام از روابط تجربى در اين جدول مشخص شده است. اين ضرايب نشان مىدهد با افزايش اندازه خرده ذرات و كاهش قطر نفوذ كنده، همبستخى مربوط به روابط تجربى افزايش يافته است. كمترين ضريب تعيين به خرده ذرات r ميلىمترى كه با نفوذكندة ا ميلىمترى

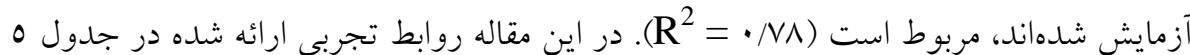
بهنوان روابط تجربى اوليه' معرفى شدهاند.

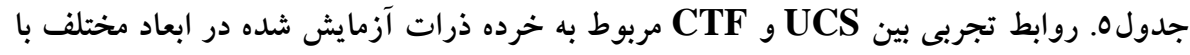

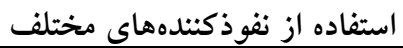

\begin{tabular}{|c|c|c|c|c|}
\hline قطر نفوذ كننده (mm) & $\begin{array}{c}\text { نمونه } \\
\text { (أندازه } \\
\end{array}$ & رابطه تجربى & ضريب تعيين ( R & شناسه رابطه \\
\hline \multirow{3}{*}{$\cdot / 7$} & $r$ & $\mathrm{UCS}=0.65(\mathrm{CTF})+9.48$ & $\cdot / \Lambda \Lambda$ & 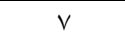 \\
\hline & r & $\mathrm{UCS}=0.46(\mathrm{CTF})+17.59$ &.$/ 94$ & $\wedge$ \\
\hline & $\varepsilon$ & $\mathrm{UCS}=0.36(\mathrm{CTF})+25.80$ &.$/ 94$ & 9 \\
\hline \multirow{3}{*}{$\cdot / \wedge$} & r & $\mathrm{UCS}=0.61(\mathrm{CTF})-25.88$ & $\cdot / A V$ & 1. \\
\hline & r & $\mathrm{UCS}=0.34(\mathrm{CTF})+14.1$ & $\cdot / 9 \varepsilon$ & 11 \\
\hline & $\varepsilon$ & $\mathrm{UCS}=0.28(\mathrm{CTF})+21.71$ & $\cdot / 17$ & ir \\
\hline \multirow{3}{*}{1} & r & $\mathrm{UCS}=0.63(\mathrm{CTF})-58.75$ & $\cdot / v \wedge$ & ir \\
\hline & r & $\mathrm{UCS}=0.26(\mathrm{CTF})+20.01$ & $\cdot / 10$ & $1 \varepsilon$ \\
\hline & $\varepsilon$ & $\mathrm{UCS}=0.19(\mathrm{CTF})+30.16$ & $\cdot / \wedge \varepsilon$ & 10 \\
\hline
\end{tabular}

ا. همبستخى بين CTF و UCS با استفاده از رخرسيون جند متغيره

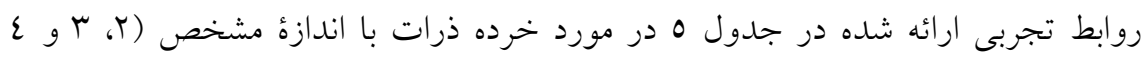

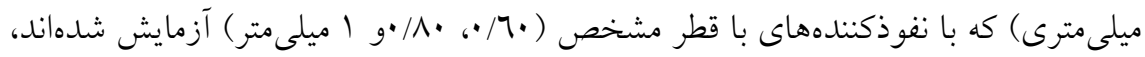

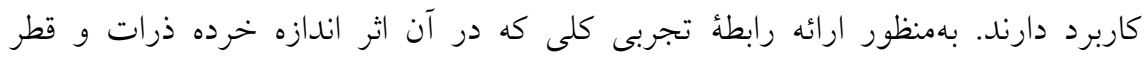
نفوذكنده لحاظ شده باشد از ركرسيون جند متغيره استفاده شده است. در اين روش متغيرهاى مستقل و وابسته بردازش شده و اثر هر يك از متغيرهاى مستقل بر متغيرهاى وابسته تعيين 
اولين متغير مستقل تأثير گذار در همبستخى CTF -UCS اندازه خرده ذرات است. در شكل 1 أر ميانخين CTF بهازاى اندازه خرده ذرات كه همكى با نفوذكندهاى با قطر يكسان (N/ ميلى متر) آزمايش شدهاند، با يكديخر مقايسه شده، جنانكه در شكل ^ مشاهده مىشود، با افزايش اندازه خرده ذرات، CTF مربوط به نمونههاى آزمايش شده، افزايش يافته است.

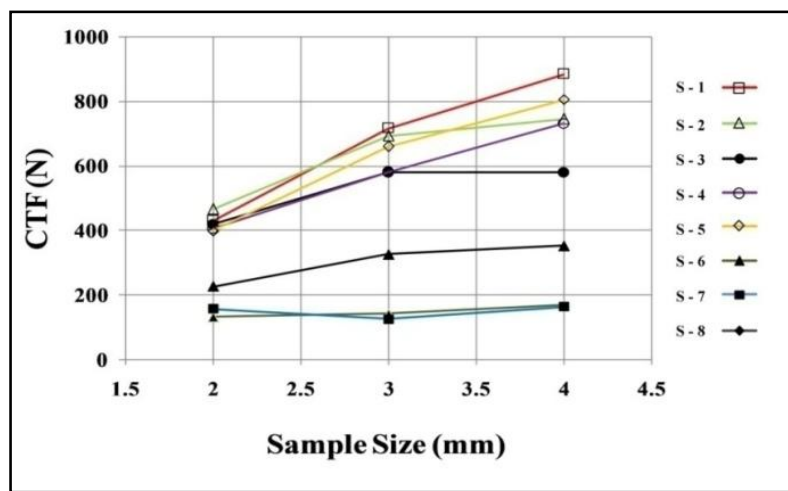

شكل ^. مقايسة ميانخين مقادير CTF مربوط به خرده ذرات در اندازههاى مختلف كه با نفوذ

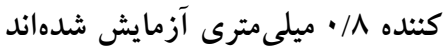

قطر نفوذكنندهُ بهكار رفته در آزمايش نفوذ، دومين متغير مستقل تأثير كذار در همبستكى هاى برقرار شده است. در شكل 9 تغيير ميانخين مقادير CTF مربوط به خرده ذرات ب ميلىمترى بهازاء افزايش قطر نفوذكننده نشان داده شده، با افزايش قطر نفوذكننده، ميانخين CTF اندازه كيرى شده افزايش يافته است.

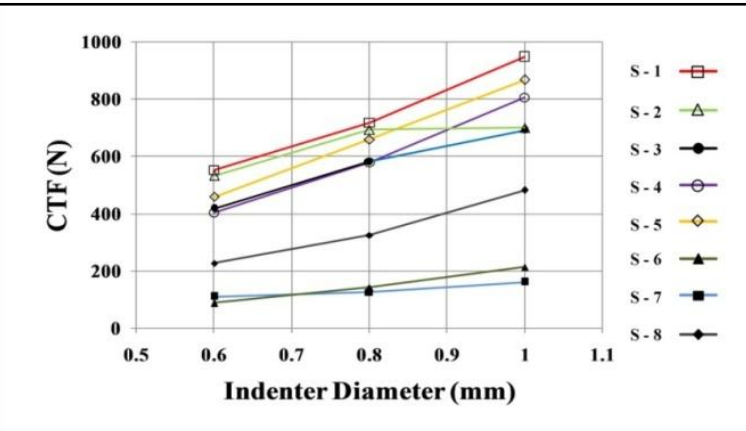

شكل 9. مختلف آزمايش شدهاند 
ميانكين CTF به خصوصيات مواد' تشكيلدهندة خرده ذرات وابسته است و بهعنوان

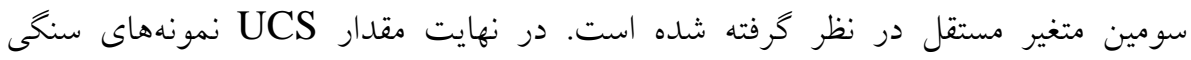

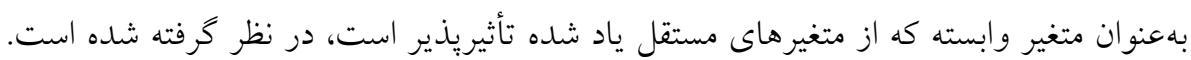

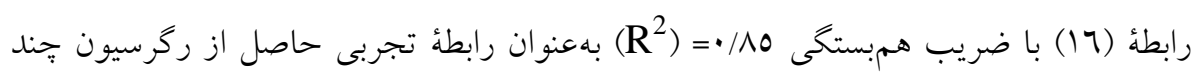

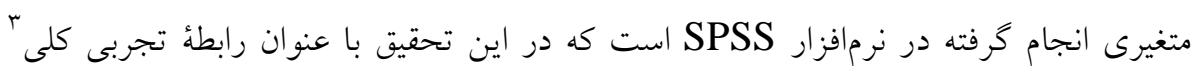
معرفى شده است: $\mathrm{R}^{2}=0.85, \quad U S C=0.29(C T F)-41.28(D)-186.47(I)+317.63$ (17) در رابطة مذكور D، اندازهُ خرده ذرات آزمايش شده و I قطر نفوذكنده بهكار رفته در آزمايش نفوذ است. با توجه به ضريب همبستخى بالا انتظار مىرود رابطؤ فوق در تخمين

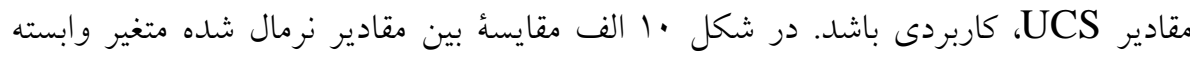

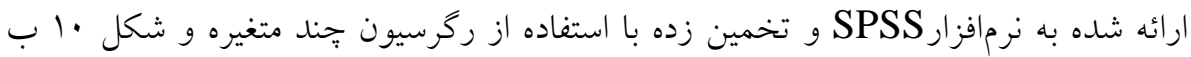

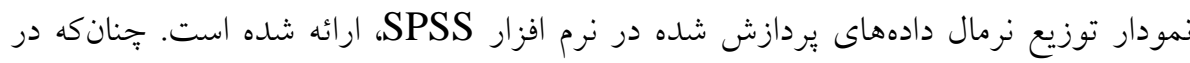
شكل مشاهده مىشود، توزيع دادهاى مربوطه نرمال است و مقادير تخمين زده و اندازهكيرى تردي شده با اختلاف كمى بههم نزديك هستند. r. ارزيابى صحت روابط تجربى ارائه شده بهمنظور ارزيابى صحت روابط بهدست آمده از ركرسيون خطى (روابط V تا 10) بهعنوان روابط تجربى اوليه و رابطة (17) كه با استفاده از كرسيون جند متغيره بهدست آمده بهعنوان

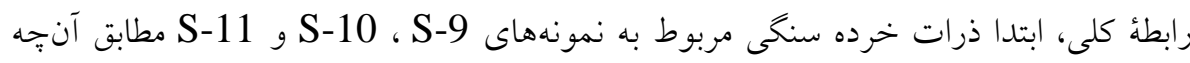

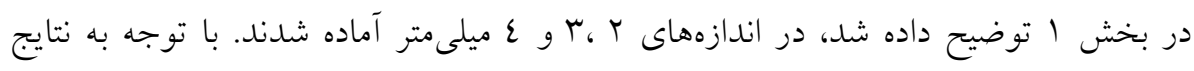

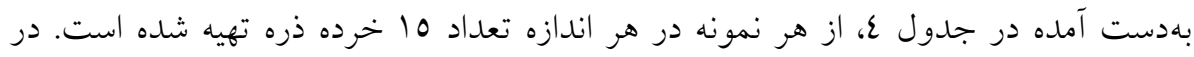
اين حالت 0 خرده ذره در هر اندازه با استفاده از نقوذ كنندهاى 7/•، A/• و ا ميلىمترى

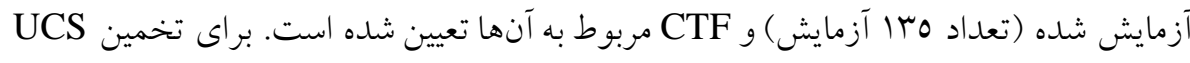


نمونها ابتدا از روابط تجربى اوليه (روابط موجود در جدول 0) استفاده شده و مقادير UCS هر نمونه تخمين زده شده است. علاوه بر آن با توجه به مشخص بودن اندازه خرده ذرات

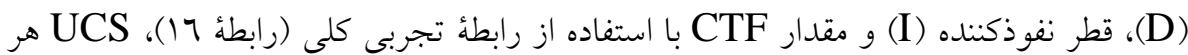

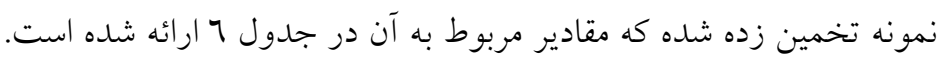

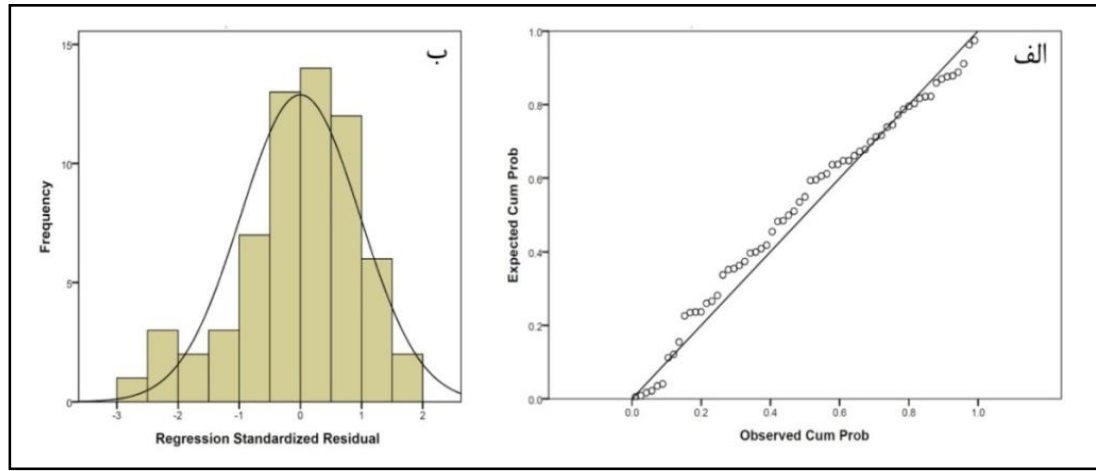

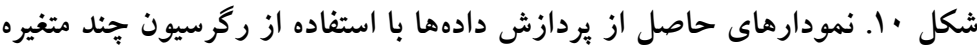

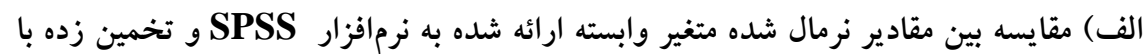

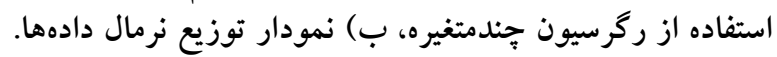

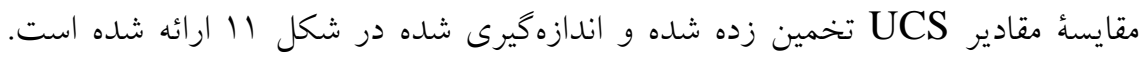
بهمنظور دقت كمى تخمين مقادير UCS از ميزان خطاى تخمين 'استفاده شده است. درصد

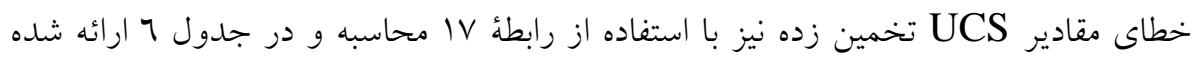

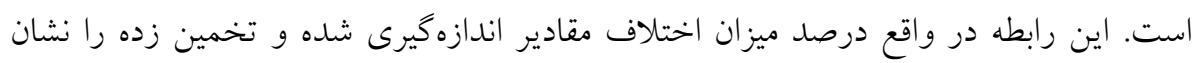
مىدهد. مقدار درصد خطاى تخمين در صورتى كه مقادير تخمين زده و اندازهكيرى شده به بههم

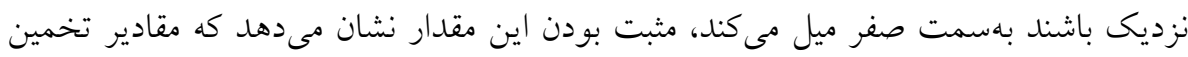

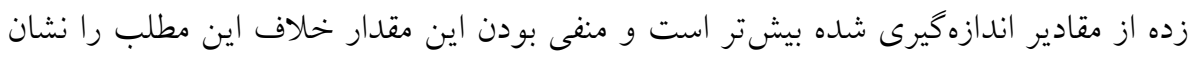

$$
\text { E.e. }=\left(\frac{E_{U C S}}{M_{U C S}}-1\right) \times 100
$$

در رابطةُ مذكور E.e.، و

1. Error of Estimation

شده و UCS محاسبه شده هستند. 
جدول 7. مقادير ميانخين UCS اندازهيرى شده و تخمين زدو انده با استفاده از روابطه تجربى اوليه

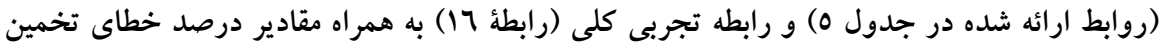
مربوط كلم

\begin{tabular}{|c|c|c|c|c|c|c|c|c|}
\hline شنا & $\begin{array}{l}\text { UCS } \\
\text { كيرى }\end{array}$ & نفوذكند & $\begin{array}{l}\text { ندونه } \\
\text { نمونه } \\
\text { (mm) } \\
\end{array}$ & $\begin{array}{c}\text { CTF } \\
(\mathbf{N})\end{array}$ & $\begin{array}{c}\text { UCS } \\
\text { تخمين زده استفاده از }\end{array}$ & تخاديرخطاى & 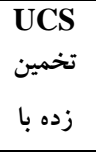 & مقاديرخطاى \\
\hline \multirow{9}{*}{ S-9 } & \multirow{9}{*}{$177 / \% 0$} & \multirow{3}{*}{$\cdot / 7$} & r & $r \mid r / O$. & $1 \varepsilon V / 7$. & $-11 / r 7$ & $110 / r Y$ & $11 / r \varepsilon$ \\
\hline & & & $r$ & MN/NI & $1 V r / r q$ & $\varepsilon / r r$ & $11 \cdot / v 9$ & $\Lambda / \top \Lambda$ \\
\hline & & & $\varepsilon$ & $r q T / \varepsilon V$ & $17 V / \cdot 1$ & $\cdot / \varepsilon \varepsilon$ & $100 / \%$. & $-7 / v$ \\
\hline & & \multirow{3}{*}{$\cdot / \Lambda$} & r & rVq/M & $1 \varepsilon \varepsilon / \wedge \varepsilon$ & $-1 T / 9 Y$ & $17 V / 7$. & $\cdot / V_{0}$ \\
\hline & & & $r$ & $r v q / \cdot T$ & $\mid \varepsilon r / q \Lambda$ & $-1 \varepsilon / \cdot \varepsilon$ & $100 / K \Lambda$ & $-1 / 70$ \\
\hline & & & $\varepsilon$ & ETO/Tr & $|\varepsilon \cdot / M|$ & $-10 / \mu$. & $1 \mathrm{ro}^{\prime} / \varepsilon \mathrm{V}$ & $-11 / 07$ \\
\hline & & \multirow{3}{*}{1} & r & $r \varepsilon r / l r$ & $107 / v 9$ & $-0 / V \varepsilon$ & $1 \varepsilon \Lambda / \varepsilon q$ & $-1 \cdot / V r$ \\
\hline & & & $r$ & $29 \Lambda / 1 Y$ & $1 \varepsilon 9 / 0 r$ & $-1 \cdot / 11$ & IOT/VO & $-\Lambda / I V$ \\
\hline & & & $\varepsilon$ & سז/7רו & $100 / 11$ & זس/1- & $17 \pi / r \Lambda$ & $-1 / \wedge \varepsilon$ \\
\hline \multirow{9}{*}{ S-11 } & \multirow{9}{*}{$r 7 \cdot / 20$} & \multirow{3}{*}{$\cdot / 7$} & r & roq/or & $r \varepsilon r / \backslash \Lambda$ & - & TYN/IT & $-1 T / r q$ \\
\hline & & & $r$ & ONT/VV & Y^O/7T & $9 / 7$ & TOY $/ .0$ & \\
\hline & & & $\varepsilon$ & Ho/9r & TVT/NT & $\varepsilon / V 1$ & $r \varepsilon \cdot / \wedge q$ & $-V / 01$ \\
\hline & & \multirow{3}{*}{$\cdot / \Lambda$} & r & $\varepsilon r o / q r$ & $r \varepsilon \cdot / \cdot r$ & $-V / \Lambda r$ & $r \mid r / I V$ & $-11 / 10$ \\
\hline & & & $r$ & $T V \varepsilon / \varepsilon \varepsilon$ & $r \varepsilon r / \varepsilon$. & $-7 / 0 \varepsilon$ & rEl/or & $-V / T T$ \\
\hline & & & $\varepsilon$ & $261 / 09$ & rrV/vo & $-\Lambda / V I$ & TYN/TI & $-I Y / T Y$ \\
\hline & & \multirow{3}{*}{1} & r & $\varepsilon 7 \cdot / 20$ & سז/וT & $-11 / 1 \mathrm{~V}$ & $\mid \Lambda \mu / \cdot \varepsilon$ & $-Y q / V Y$ \\
\hline & & & $r$ & $1 / r / 70$ & TrI/00 & $-11 / \cdot 9$ & 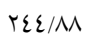 & $-0 / 9 V$ \\
\hline & & & $\varepsilon$ & $11 \cdot r / .0$ & rrq/VE & $-V / 90$ & TMN/l. & $-1 \cdot / 71$ \\
\hline \multirow{9}{*}{ S-12 } & \multirow{9}{*}{ r.. } & \multirow{3}{*}{$\cdot / 7$} & r & $T Y V / \cdot 0$ & $10 \mathrm{~V} / \cdot \mathrm{T}$ & $-r I / \varepsilon T$ & $\mid \wedge q / \varepsilon V$ & $-0 / Y 7$ \\
\hline & & & $r$ & MTY/AV & $|\wedge \varepsilon / 0|$ & $-V / V \varepsilon$ & IAV/AO & $-7 / \cdot v$ \\
\hline & & & $\varepsilon$ & ET/OT & $1 \mathrm{~V} / 0 \varepsilon$ & $-11 / r T$ & $17 \pi / 41$ & $-11 / 17$ \\
\hline & & \multirow{3}{*}{$\cdot / \wedge$} & r & r90/NT & $10 \varepsilon / T V$ & $-Y Y / \Lambda T$ & $I V T / T$ & $-11 / 9 \varepsilon$ \\
\hline & & & $r$ & $\varepsilon \cdot \Lambda / r$. & $10 r / 94$ & מr/or & $17 \pi / \wedge 1$ & $-11 / \cdot 9$ \\
\hline & & & $\varepsilon$ & OY $/ T$. & $\mid W / \varepsilon \wedge$ & $-10 / 20$ & $107 / \mathrm{rV}$ & $-Y \mid / \Lambda I$ \\
\hline & & \multirow{3}{*}{1} & r & ror/Ao & $17 \varepsilon / 18$ & $-|V / 9|$ & $101 / 91$ & $-r \varepsilon / \cdot \varepsilon$ \\
\hline & & & $r$ & 0 Ora/ro & $10 V / 7 \varepsilon$ & $-Y I / I V$ & $171 / A V$ & $-19 / \cdot 7$ \\
\hline & & & $\varepsilon$ & $U V / \cdot \varepsilon$ & $17 \cdot / 79$ & $-19 / 70$ & אר/77 & $-17 / 71$ \\
\hline
\end{tabular}


با توجه به جدول 7، روابط تجربى اوليه با خطاى كمترى (بهطور ميانخين الVI/VI درصد)

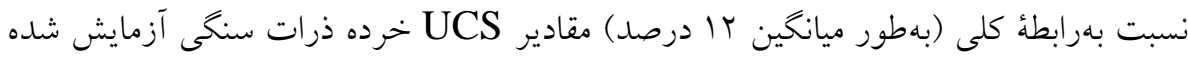
را تخمين زدهاند. در مجموع مىتوان اذعان داشت، مقادير بهدست آمده از رابطهُ كلى نيز بهخوبى روابط تجربى اوليه قابليت تخمين مقادير UCS مربوط به نمونههاى سنخ آهك ميكرايتى را داراست. بنا بر اين روابط ارائه شده قادرند مقادير UCS مربوط به نمونههاى سنكى آهك ميكرايتى را با كمتر از با درصد خطا تخمين بزنند.
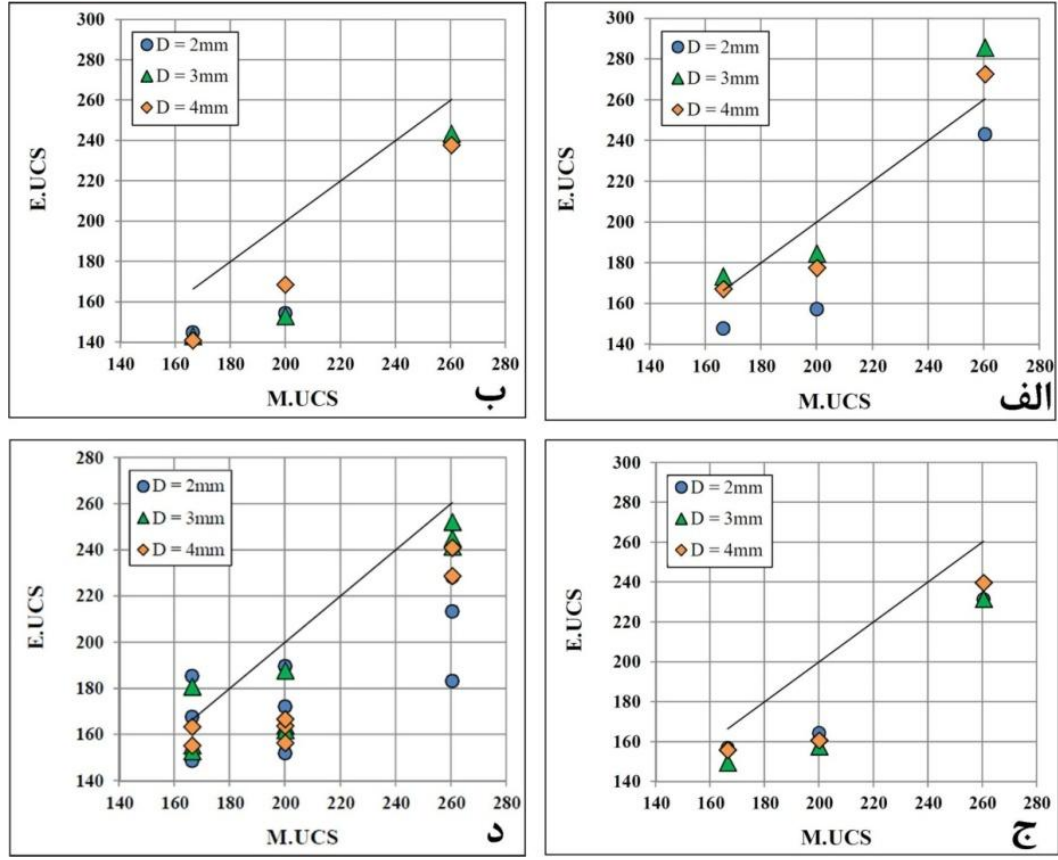

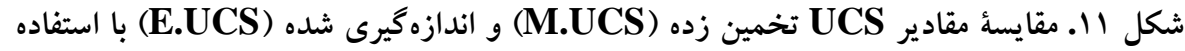

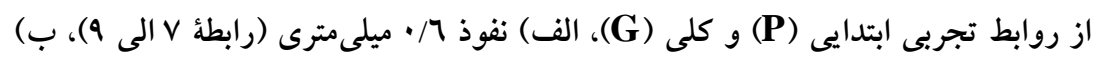

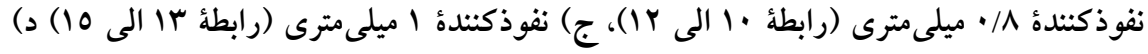
رابطة كلى (رابطه 17 ) 


\section{نتيجه گيرى}

در اين مقاله براى تخمين غيرمستقيم UCS، استفاده از خرده ذرات سنكى بيشـنهاد شـــ و

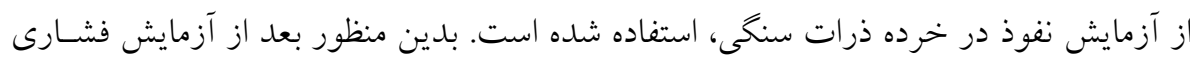

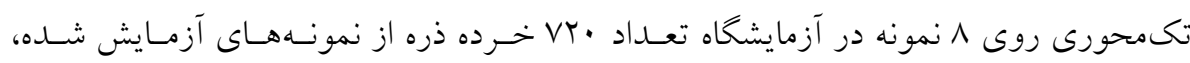

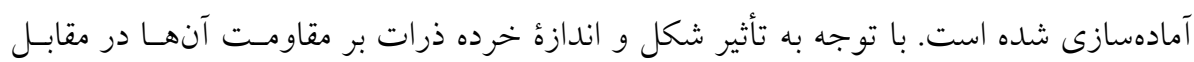

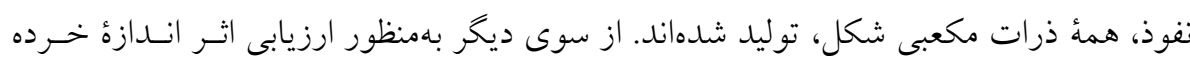

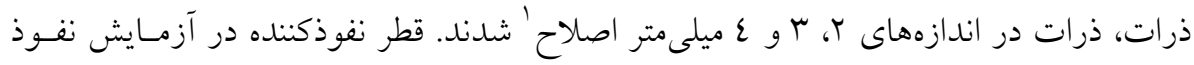

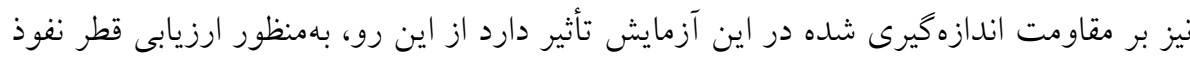

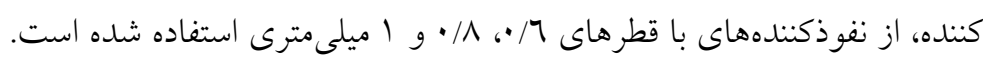

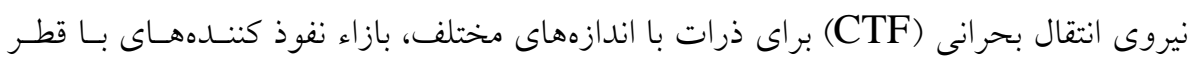

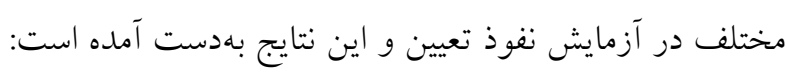

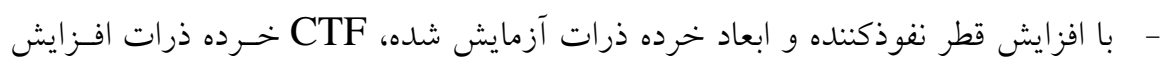

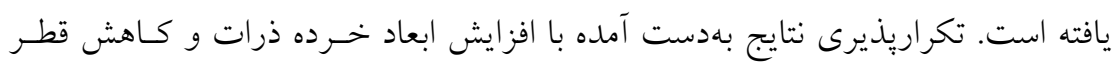
نفوذكننده، افزايش يافته است.

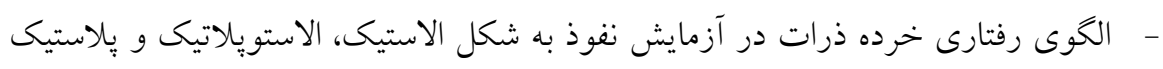

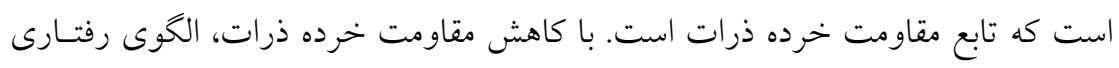

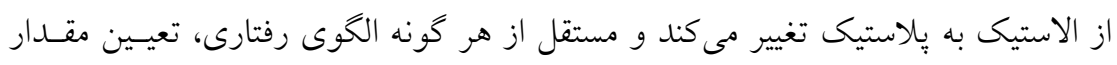

$$
\text { CTF }
$$

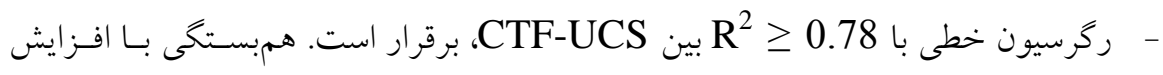

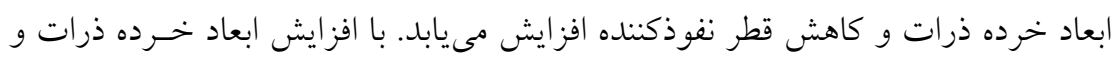

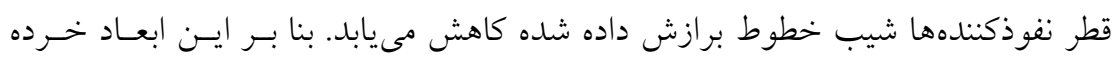

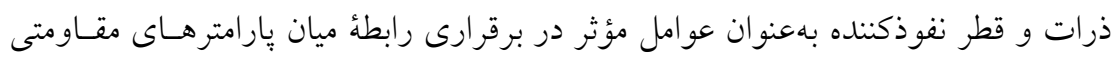
در نظر كرفته شده است. 
با استفاده از تحليل آمارى رگرسيون جند متغيره رابطهاى تجربى بين اندازه خرده ذرات، قطـر

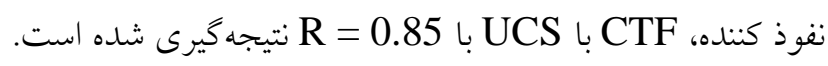

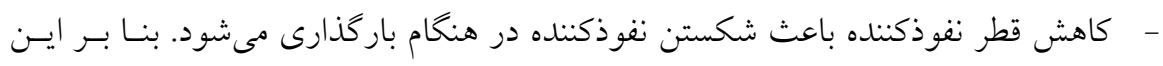

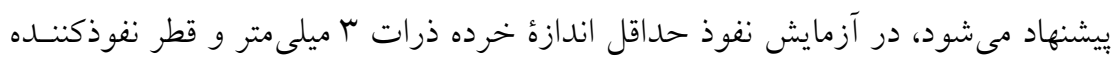
ا ميلى متر باشد. - - بهمنظور ارزيابى صحت روابط بهدست آمده، هبا آزمايش باركــارى بـر خـرده ذرات

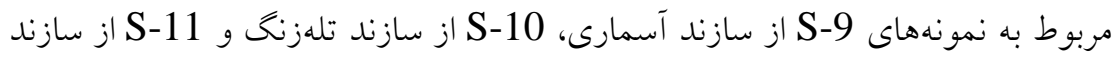

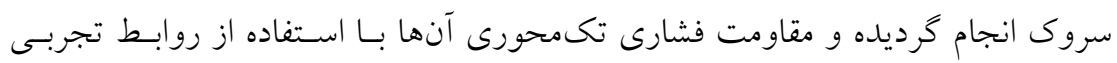

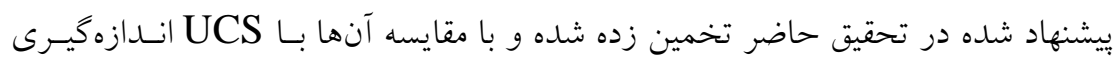

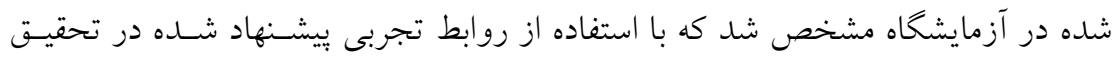

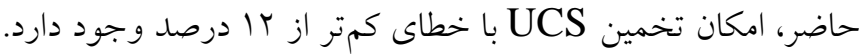
- امكان تخمين مقاومت فشارى تكمحورى سنك آهك ميكرايتى بـا استفاده از آزمايش

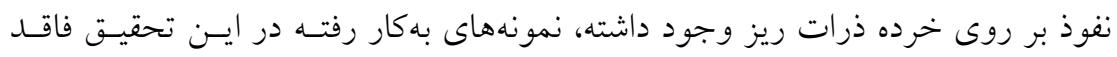

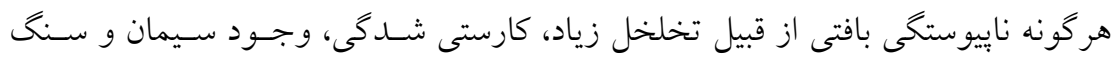

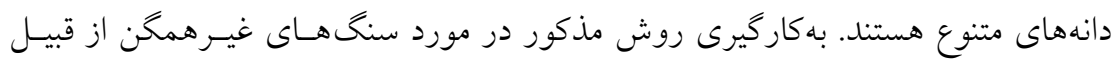

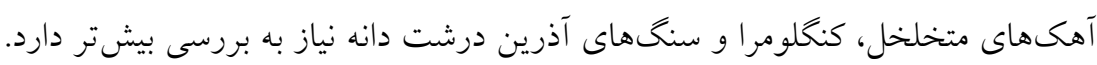

\section{تشكر و قدردانى}

بدينوسيله از صندوق حمايت از يُزوهش كران و فناوران كشور (معاونت علمى و فناورى

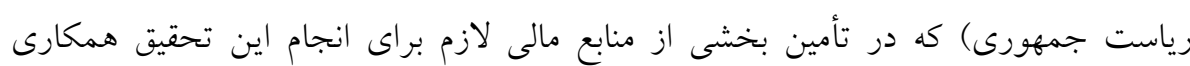
كردند تشكر و قدردانى مى شود. 


\section{منابع}

1. Bieniawski Z.T., "Estimating the strength of rock materials", Journal of the South African Institute of Mining and Metallurgy, Vol. 74 (1974). 312-320.

2. Cargill J.S., Shakoor A., "Evaluation of empirical methods for measuring the uniaxial compressive strength of rock", International Journal of Rock Mechanics and Mining Sciences Vol.27 (1990) 495-503.

3. Zhang L., "Engineering properties of rocks", Elsevier Geo-Engineering Book Series Vol.4 (2005).

4. Lacharite N., "A study to correlate the shearing, bending and compression properties of rock", Fuels and Min Pract Div, Mines Branch, Can Dept Mines and Tech Surv, Ottowa, IR 60/38FMIN (1960).

5. Mazanti B.B., Sowers G.F., "Laboratory testing of rock strength. In: Proceedings of the International Symposium on Testing Techniques for Rock Mechanics", Seattle, Washington (1965) 207-27.

6. Vutukuri V.S., Lama R.D., Saluja S.S., "Handbook on Mechanical Properties of Rocks", Trans Tech Publications Clausthal, Germany Vol. 1 (1974).

7. Schrier vander J.S., "The block punch index test", Bull Int Assoc Eng. Geol.; Vol. 38 (1988) 121-126.

8. Sulukcu S., Ulusay R., "Evaluation of the block punch index test with particular reference to the size effect, failure mechanism and its 
effectiveness in predicting rock strength", International Journal of Rock Mechanics \& Mining Sciences Vol. 38 (2001.) 1091-1111.

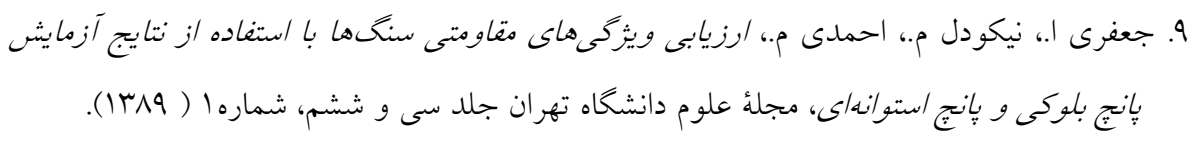

10. Yilmaz I., "A new testing method for indirect determination of the unconfined compressive strength of rocks", International Journal of Rock Mechanics \& Mining Sciences Vol. 46 (2009) 1349-1357.

11. Kayabali K., Selcuk L., "Nailpenetration test for determining the uniaxial compressive strength of rock", International Journal of Rock Mechanics \& Mining Sciences Vol. 47 (2010) 265-271.

12. Santarelli F.J., Marshala A.F., Brignoli M., Rossi E., \& Bona N., "Formation Evaluation from logging on cuttings", SPE Permian Basin Oil and Gas Recovery Conference, Midland, Texas, March 27-29. SPE 36851 (1996).

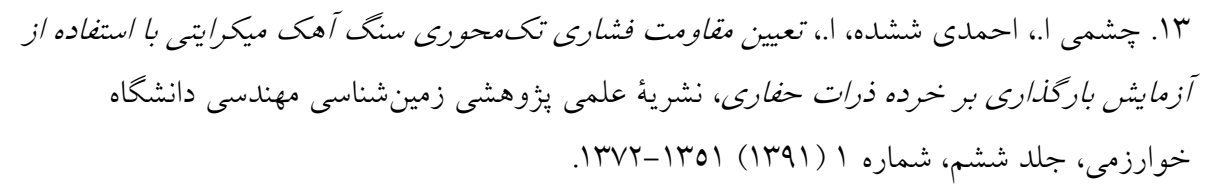

14. Mehrabi Mazidi S., Haftani M., Bohloli B., CheshomiA., "Measurement of uniaxial compressive strength of rocks using reconstructed cores from rock cuttings", Journal of Petroleum Science and Engineering (2012).

15. Nes O.M., Horsrud P., Sonstebo E.F., Holt R.M., "Rock physics from small sampels-sometimes your only solution", SCA-58 (2001).

16. Zorlu K., Gokceoglu C., Ocakoglu F., Nefeslioglu H.A., Acikalin S., "Prediction of uniaxial compressive strength of sandstones using 
petrography-based models", Engineering Geology Vol. 96 (2008) 141158.

17. Alber M., Kahraman S., "Prediction the Uniaxial Compressive Strength and Elastic Modulus of a fault Breccia from Texture coefficient", Rock Mechanics and Rock Engineering Vol. 42 (2009) 117-127.

18. Ringstad C., Lofthus E.B., Sonstebo E.F., Fjær E., Zausa F., and Giin-Fa Fuh., "Prediction of rock parameters from micro-indentation measurements: The effect of sample size", EUROCK'98, Trondheim, Norway, July 8-10. SPE 47313 (1998).

19. Zausa F., Civolani L., Brignoli M., Santarelli F.J., "Real timewellbore stability analysis at the rigsite", SPE/IADC Drilling Conference, Amsterdam, The Netherlands, March 4-6. SPE 37670 (1997).

20. Uboldi V., Civolani L., Zausa F., "Rock strength measurements on cutting as input data for optimizing drill bit selection", SPE Annual Conference and Exhibition, Houston, Texas, October 3-6. SPE 56441 (1999).

21. Mateus J., Saavedra N.F., Calderón Z.H., Mateus D., "Correlation development between indentation parameters and uniaxial compressive strength for Colombian sandstones", CT\&F-Ciencia Tecnologíay Futuro. Vlo. 3 (2007) 125-135.

22. García R.A., Saavedra N.F., Zuly C.C., Mateus D., "Development of experimental correlations between indentation parameters and unconfined 
compressive strength (UCS) values in shale samples", CT\&F-Ciencia Tecnologíay Futuro, Vol. 3 (2008) 61-81.

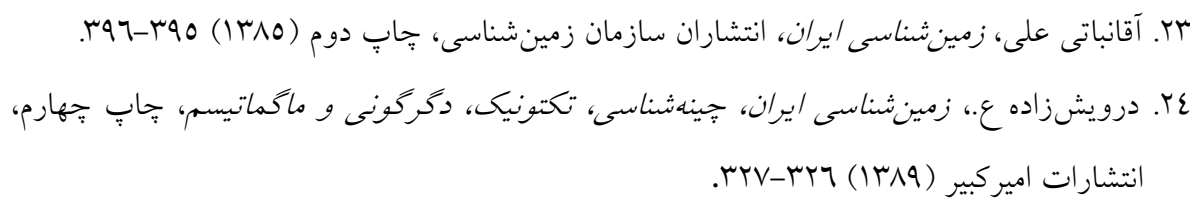

25. ISRM Suggested Methods, In: Brown ET, editor. "Rock characterization testing and monitoring" Oxford: Pergamon Press (1981).

26. Bieniawski Z.T., "Engineering classification of jointed rock masses", Trans S Afr Inst Civ. Eng. Vol. 15 (1973) 335-344.

27. Coates D.F., "Classification of rock for rock mechanics", Int J.Rock Mech. Min. Sci. Vol.1 (1964) 421-429.

28. Deere D.U., Miller R.P., "Engineering classification and index properties of intact rock", Air Force Lab Tech Rep AFNLTR Vol. 65 (1966).

29. British Standard Institution, "Code of practice for site investigations" BS 5930 HMSO, London (1981).

30. Broch E.M., Franklin J.A., "The point load strength test", Int.J. Rock Mech. Min. Sci.Vol. 9 (1972) 669-697.

31. Obert L., Duvall W., "Rock Mechanics and The Design Of Structures In Rock", John Wiley \& Sons (1967).

rr. احمدى ششده ابراهيم، طراحى و ساخت دستكاه باركذارى بر خرده ذرات مجزا و برزسى

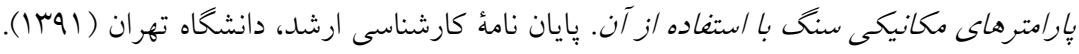

33. Gill D., E., Corthe'sy R., Leite M., H., "Determining the minimal number of specimens for laboratory testing of rock properties", Engineering Geology Vol. 78 (2005) 29-5. 